2018

\title{
Patent Jobs and the Myth of the Employment Hypothesis
}

\author{
Kenneth L. Port \\ Mitchell Hamline School of Law, ken.port@mitchellhamline.edu \\ Lucas Hjelle \\ Molly Litman
}

Follow this and additional works at: https://open.mitchellhamline.edu/cybaris

Part of the Intellectual Property Law Commons, and the Legal Education Commons

\section{Recommended Citation}

Port, Kenneth L.; Hjelle, Lucas; and Litman, Molly (2018) "Patent Jobs and the Myth of the Employment Hypothesis," Cybaris®: Vol. 9 : Iss. 2 , Article 1.

Available at: https://open.mitchellhamline.edu/cybaris/vol9/iss2/1

This Article is brought to you for free and open access by the Law Reviews and Journals at Mitchell Hamline Open Access. It has been accepted for inclusion in Cybaris ${ }^{\circledR}$ by an authorized administrator of Mitchell Hamline Open Access. For more information, please contact sean.felhofer@mitchellhamline.edu. (c) Mitchell Hamline School of Law

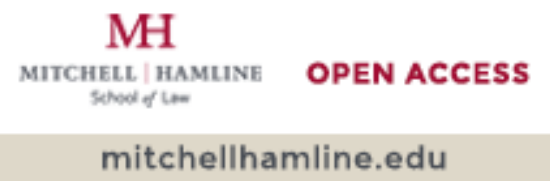




\section{PATENT JOBS AND THE MYTH OF THE EMPLOYMENT HYPOTHESIS}

By Kenneth L. Port, LuCAs HJelle, AND MOLly LitTMan

\section{TABLE OF CONTENTS}

I. INTRODUCTION............................................. 131

II. THE PROBLEM................................................139

III. THE EMPLOYMENT HYPOTHESIS. ............................. 140

IV. PATENT JOBS COMPARED TO DEBT BURDEN.................... 149

V. PATENT ATTORNEY SALARIES COMPARED TO DOCTORAL

ENGINEERING SALARIES.....................................155

VI. HISTORY OF PH.D.s, MBA, AND ALL PH.Ds....................159

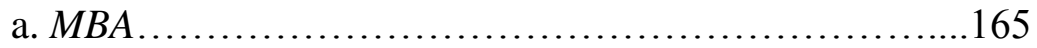

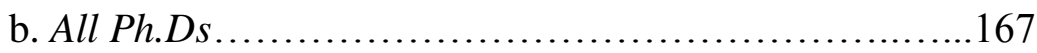

VII. LAW COMPARED TO OTHER GRADUATE DEGREES.............. 172

VIII. WHAT EXPLAINS THE DEARTH OF MECC ENGINEERS ATTENDING LAW SCHOOL? ............................................175

a. Hypothesis One: The practical vs. elite narrative is a disjointed disincentive...............................176

b. Hypothesis Two: Ph.D. as an alternative graduate degree.........................................189

c. Hypothesis Three: The Psychology of Bandwagon theory............................................190

d. Hypothesis Four: Law has no grand theory............192

e. Hypothesis Five: Legal field fails to educate MECC Engineers about patent law................................. 195

IX. CONCLUSION.............................................. 196 


\section{Introduction}

There is an anomaly and a double standard regarding the education of would-be patent lawyers in the United States today. The anomaly is that, even though patent jobs are plentiful, patent-eligible students forgo law school in numbers that far exceed the drop in enrollment of law students in general. The double standard exists because no other subject matter, be it History, Humanities in general, MBA, etc., is held to the standard where society and the media expects full employment from graduates. This article is an inquiry into the anomaly and the double standard. 
It is now no longer a secret that there is an enrollment crisis in American Law Schools. ${ }^{1}$ In our prior work, we located data to support the notion that the crisis in educating would-be patent attorneys - those with degrees in patent bar eligible subjects - is significantly worse than in all attorneys in general. ${ }^{2}$ The accepted explanation $^{3}$ for why people are abstaining from obtaining a legal education is the idea that law school is no longer a wealthmaximizing proposition. Reports abound about how J.D. holders need to seek employment in areas other than law to pay back the staggering debt incurred in obtaining the degree. Some students have even elected to sue their law schools for allegedly misleading them about their likely prospects of obtaining employment as an attorney. ${ }^{4}$ All have either lost summarily ${ }^{5}$ or lost at trial. ${ }^{6}$

${ }^{1}$ Frank H. Wu, The End(s) of Legal Education, 66 J. LEGAL EDUC. $18,22-23$ (2016). One of the primary sources of this crisis is between schools enrolling students to keep the school solvent while also ensuring the school itself maintains its place in the rankings. $I d$. at 22 .

${ }^{2}$ Kenneth L. Port et al., Where Have all the Patent Lawyers Gone? Long Time Passing . . 97 J. PAT. \& TRADEMARK OFF. SOC'Y 193, 213 (2015) [[hereinafter Gone?]. We predicted that, by 2018, new patent bar entrants will be half of what they were in 2008. Id. In the twelve months leading up to March 2017, 569 attorneys passed the Patent Bar and received patent bar registration numbers. This number is slightly more than half of the per-year average of 1105 attorneys receiving registration numbers for the preceding dozen years between 2002 and 2013. As of April 26, 2017, there were 11346 active patent agents and 33962 active patent attorneys, though it is unclear how many of these are actively working as patent agents or patent attorneys. Patent Practitioner Home Page, USPTO, https://oedci.uspto.gov/OEDCI/ (Apr.Apr. 26, 2017). See also, Kenneth L. Port, et al., In Pursuit of Patent Quality (and Reflections of Reification), 20 MARQ. INTELL. PROP. L. REV. 79 (2016) [hereinafter Patent Quality]. 
${ }^{3}$ Although criticism of law schools and the work law professors do abound, it all can be encapsulated in the conversation about normative legal scholarship. That is, within the discipline (professors and the bar), there are harsh criticisms of what professors write and by extension how they teach. There has been a raging debate for a long time between the camp that believes a law professor's job is to describe the law while others believe that the job is to improve the law and seek truth and/or justice. See generally, Robin West, The Contested Value of Normative Legal Scholarship, 66 J. LEGAL ED. 6 (2016); Stanley Fish, Save the World on Your Own Time 22 (2012) (describing the tensions between and within the legal profession and academia itself surrounding normative legal scholarship). This has led some practitioners, once they are in practice, to look back at their legal education and wonder what the value of it truly was as what their professors were writing and talking about did not comport with the reality they saw as a practitioner.

${ }^{4}$ See Andrew S. Murphy, Redeeming a Lost Generation: "The Year of Law School Litigation" and the Future of the Law School Transparency Movement, 88 IND. L. J. 773 (2013).

${ }^{5}$ Sara Randazzo, Jobless grads Who Sued Law Schools Find More Rejection in Court, WALl ST. J. (Oct. 15, 2015), http://blogs.wsj.com/law/2015/10/15/jobless-grads-who-sued-lawschools-find-more-rejection-in-court/?mg=id-wsj.

${ }^{6}$ Elizabeth Olson, Law Graduate Who Sued Her School Loses at Trial, N.Y. TIMES (Mar. 24, 2016), https://www.nytimes.com/2016/03/25/business/dealbook/lawgraduate-who-sued-her-school-loses-at-trial.html. See also Olson, infra note 12; Andrew S. Murphy, Redeeming a Lost Generation: "The Year of Law School

Litigation" and the Future of the Law School Transparency Movement, 88 IND. LAW J. 773 (2013). 
But for one easily identifiable group, the legal job market is strong and growing: job prospects for Mechanical, Electrical, Chemical, and Computer Engineers (hereinafter, "MECC Engineers") are quite positive. ${ }^{7}$ However, despite these positive job prospects, the number of MECC Engineers coming to law school is at near-record lows. ${ }^{8}$ The decrease in the number of MECC Engineers enrolled in law schools far exceeds the decrease in non-patent-bar-eligible law students. ${ }^{9}$

${ }^{7}$ See the discussion at infra, note 24 .

${ }^{8}$ Infra, notes 36,37 , and 38.

${ }^{9}$ See Gone?, supra note 2, at 198-99. 
The factors that might lead MECC Engineers to shy away from law school are, at least in part, fueled by the media. ${ }^{10}$ The media, in the form of the New York Times ${ }^{11}$ and others, ${ }^{12}$ has often reported on reasons why obtaining a law degree is a mistake. But what these articles fail to do is differentiate the job market across different areas of the law. While law school might not be a wealth maximizing proposition for every law student and for every area of law, it is indeed beneficial for MECC Engineers. And while the media is not directly responsible for the decrease in law school enrollment, it certainly does not help the problem by incorrectly reporting the prospects of obtaining legal employment upon graduating from law school, particularly for MECC Engineers.

Rather, these articles perpetuate the notion that every single person with a law degree should easily find a job and effortlessly pay off of his or her student loans. Law schools have also adopted-and often perpetuated - this notion that each law school has an obligation to provide each law student with a job that requires a J.D degree. ${ }^{13}$ This is referred to herein as the "Employment Hypothesis." The Employment Hypothesis is the phenomenon in which people believe that a J.D. degree should be achieved at little or no net $\operatorname{cost}^{14}$ to the student or, at least, that a J.D. degree should provide the student an quick return on investment. The Employment Hypothesis is further predicated on the notions that debt burdens are too large to be repaid and that a lawyer does not earn an attractive salary compared to a job one could hold without a JD degree. Most interesting, however, is the idea there is something unique about the practice of law; that each student has a reasonable expectation of obtaining a job that requires a J.D. degree upon completion of their education. As explained below, no other degree approaches job prospects under such a hard and fast rule. 
10 These range from those stories of law school graduates who are burdened with debt and cannot find a job in a big firm and, therefore, elect other work, often those that don't require a law license. Elizabeth Olson, Burdened With Debt, Law School Graduates Struggle in Job Market, N.Y. TIMES (Apr. 26, 2015), http://www.nytimes.com/2015/04/27/business/dealbook/burdenedwith-debt-law-school-graduates-struggle-in-job-market.html. There are tales of students borrowing upwards of $\$ 100-\$ 200,000$, with details about financial consequences in the future as they struggle to get legal positions. Noam Scheiber, Expensive Law degree, and No Place to Use It, N.Y. TIMES (Jun. 17, 2016), http://www.nytimes.com/2016/06/19/business/dealbook/anexpensive-law-degree-and-no-place-to-use-it.html. Law school tuition and debt has "surged at inflation-adjusted rates of 25 percent for private schools and 34 percent for public schools", and since " 25 percent of law schools obtain at least 88 percent of their total revenues from tuition", with the average being $69 \%$, there's "a powerful incentive to maintain or increase enrollment, even if the employment outcomes are dismal for their graduates, especially at marginal schools." Steven J. Harper, Too Many Law students, Too Few Legal Jobs, N.Y. TiMES (Aug. 25, 2015), http://www.nytimes.com/2015/08/25/opinion/too-many-lawstudents-too-few-legal-jobs.html. Graduating from law school with $\$ 250,000$ in debt with few job prospects, with creditors calling daily, is a "catastrophic event" according to the Times. David Segal, Is Law School a Losing Game?, N.Y. TIMES(Jan. 8, 2011), http://www.nytimes.com/2011/01/09/business/09law.html.

${ }^{11}$ See the discussion regarding the New York Times articles, supra note 4; See, e.g., Noam Scheiber, The Law School Bust, N.Y. Times(Jun. 19, 2016). Even though the fact that most of these claims have been skillfully rebutted, we, as a society, apparently are more susceptible to the claim that the house is on fire rather than the fact that the firemen have arrived and it is extinguished. See Michael Simkovic and Frank McIntyre, The Economic Value of a Law Degree, 43 J. LeGAL STUD. 249, 284-85 (2014). 
${ }^{12}$ Elizabeth Olson, Law grads take their job frustrations to court, FORTUNE (Aug. 31, 2011), http://fortune.com/2011/08/31/law-gradstake-their-job-frustrations-to-court/.

${ }^{13}$ Although posting of employment data is required by the ABA guidelines, the employment and career services pages of law schools often convert this required data posting into a marketing opportunity. This often includes touting the expected employment prospects of graduates, explaining how to decipher US News \& World Report rankings, and detailing clerkship information. See, e.g., Employment Data, YALE L. SCH., https://law.yale.edu/student-life/careerdevelopment/employment-data (Mar. 21, 2017); Graduate Employment Outcomes, STANFORD L. SCH., https://law.stanford.edu/careers/employment-outcomes/graduateemployment-outcomes/\#slsnav-employment-by-salary ( Apr. 3, 2017); Recent Employment Data, HARVARD L. SCH., http://hls.harvard.edu/dept/ocs/recent-employment-data/ (last visited April 3, 2017).

${ }^{14}$ As used herein, "net cost" refers to gross cost as offset by scholarships. 
This Employment Hypothesis is flawed. In this article, we explore the Employment Hypothesis as it applies to patent-eligible law students and patent attorneys. We conclude that the given explanation for the decline in American law school enrollment-the Employment Hypothesis - does not explain the decline in MECC Engineers attending law school because if the Employment Hypothesis was accurate, it should predict precisely the opposite: an increase in MECC Engineers attending law school, as there are plenty of MECC engineer patent attorney jobs available. Section II explains the origins of the Employment Hypothesis and the presumptions its proponents must possess to rely upon it. Section III looks at the historical levels of law school debt burden compared to historical attorney salaries and demonstrates that debt burden should not be the chilling factor in attending law school for MECC Engineers that the media portrays it. Section IV presents data comparing MECC Engineers with J.D. degrees and MECC Engineers with Ph.D. degrees in engineering and concludes that a $\mathrm{Ph}$.D. in engineering has no quantifiable advantage over a patentbar-eligible J.D. holder. Part V compares career expectancies of other disciplines and concludes that law is unique in the expectation that the degree will lead to one, discernible job - a lawyer. That is, no other discipline puts this pressure on its universities nor holds them responsible in any way if its graduate students are not employed at a job requiring the degree which they obtained. Finally, Part VI demonstrates that law graduates have never in history been employed at $100 \%$ and that to expect that now is unreasonable, even though the actual employment rate of all 2016 graduates from all law schools was nearly $92 \% 10$ months after graduation. ${ }^{15}$

${ }^{15} 2016$ Law Graduate Employment Data, AM. BAR Assoc., https://www.americanbar.org/content/dam/aba/administrative/legal_ education_and_admissions_to_the_bar/statistics/2016_law_graduate _employment_data.authcheckdam.pdf. 
This article concludes that the very Employment Hypothesis that many in the media claim ${ }^{16}$ accurately describes the enrollment crisis in American legal education actually contradicts why MECC Engineers are foregoing a law school education. With this article we attempt to pursue many explanations for the public's reliance on the Employment Hypothesis, and in particular, why MECC Engineers might choose a Ph.D. in their science over a J.D. - as they seem to be doing. In the end, this article concludes that MECC Engineers are very employable as patent attorneys if they attend law school. However, the very rationality that leads them to a degree in MECC engineering may be the rationality that diverts them from law school.

\section{The Problem}

As we have noted in past papers, ${ }^{17}$ there is a noticeable decline in the number of patent-bar-eligible MECC Engineers obtaining law degrees. By next year the number of new patent attorneys will shrink to half of what it was in 2008. ${ }^{18}$ Therefore, between the remarkably reified field that the United States has created within its patent system $^{19}$ - allowing only a particular subset of attorneys to become patent attorneys - and the increasing need for patent attorneys, ${ }^{20}$ the number of patent-bar eligible law students should, arguably, increase. Yet, the enrollment numbers for MECC Engineers continue to decline. The accepted explanation for the decline of all law students is what we refer to as the Employment Hypothesis. We will demonstrate that this Employment Hypothesis is flawed as applied to MECC Engineers as patent jobs for MECC Engineers are plentiful but still they are not coming to law school.

${ }^{16}$ See the discussion from various media articles, supra note 10.

${ }^{17}$ Gone?, supra note 2 at 198; Patent Quality, supra note 2.

${ }^{18}$ Gone?, supra note 2 at 199.

${ }^{19}$ Patent Quality, supra note 2.

${ }^{20}$ See Infra Part IV. 


\section{The Employment Hypothesis}

The Employment Hypothesis is the idea that law school has suddenly become a non-wealth maximizing proposition, including the idea that the return on investment (ROI) is no longer sufficient. It is an attractive theory because of its apparent simplicity. For example, the Employment Hypothesis may be used to support an argument that fewer lawyer jobs equates to fewer law students. However, it is also disingenuous; no other schooling is held to such a high standard of employment-tracking transparency. ${ }^{21}$ Although the number of attorneys employed at "big law" has shrunk some 52,000 people since its peak in $2007,{ }^{22}$ other data suggests that the employment picture for law graduates is quite good. ${ }^{23}$ However, the media has latched on to this idea that law school is not beneficial to the J.D. holder as an easy, essential stereotype and appears to be reluctant to do further thought and analysis of the issue. ${ }^{24}$

${ }^{21}$ Law schools and law schools' accrediting agency the American Bar Association (ABA) may have contributed to this: as the media reports things heard, law schools and the ABA do not research and find the truth. Perhaps in an attempt to heal the negative reputation that lawyers have in American society, the ABA has become the most transparent accrediting agency we could find. No other accrediting agency collects, reports out, and then ranks schools using employment data to the extent that the ABA does. In fact, in most other disciplines, it is impossible to find comparative and reliable employment data. 
${ }^{22}$ ABA National Lawyer Population Survey, A.B.A., http://www.americanbar.org/content/dam/aba/administrative/market _research/national-lawyer-population-by-state-20062016.authcheckdam.pdf (last visited Apr. 16, 2017). The American Lawyer states that the current legal industry has about 1.13 million workers, and remains 52,000 jobs below "its pre-recession high in 2007." Much reporting focuses on the drop in what National Association for Law Placement calls "Big Law" jobs, which lost many positions following the great recession; however other fields tended to compensate for it, and on the whole, job rates for lawyers have been remarkably steady over the last two decades. James G. Liepold \& Judith N. Collins, The Stories Behind the Numbers: Jobs for New Grads Over More Than Two Decades, NALP BULLETIN (December 2016), http://www.nalp.org/1216research. For a broader discussion of the effect of the Great Recession on big law firms, see Bernard A. Burk \& David McGowan, Big But Brittle: Economic Perspectives on the Future of the Law Firm in the New Economy, 2011 COLUM. BUS. L. REV. 1, 28-40 (2011). For a comprehensive explanation of what we refer to as the Employment Hypothesis, see Luz E. Herrera, Training Lawyer Entrepreneurs, 89 Denv. U.L. Rev. 887 (2012). See also, Bernard A. Burk, What's New About the New Normal: The Evolving Market for New Lawyers in the $21^{\text {st }}$ Century, 41 Fla. St. U.L. Rev. 541 (2014) (predicting that Big Law structural changes are here to stay and the United States economy will and has adjusted to fewer lawyers at Big Law); Richard W. Bourne, The Coming Crash in Legal Education: How We Got Here, and Where We Go Now, 45 Creighton L. Rev. 651, 659 (2012) ("Unless law schools reconfigure themselves, many will die on the vine, crushed by cost-structures incurred during good times and starved by an unwillingness of students to incur everincreasing indebtedness to train for a much tighter job market."). Richard Matasar may be the first to recognize the effect of falling employment numbers may have on law schools when he wrote in 1994 as follows: 
Students must bear the brunt of financing the expansion of new educational programs. The bad news is that students may not be as willing to do so today as they have been over the last decade. During that time, students have been able to finance their increasing educational cost by gambling that a strong placement market - with lots of jobs and firms that absorb increasing numbers of new graduates at ever-higher salaries - will always exist. Unfortunately for the gamblers, that era seems to be ending.

Richard A. Matasar, The MacCrate Report from the Dean's Perspective, 1 Clinical L. Rev. 457, 467 (1994) (discussing the economics of legal education in 1994). See also, Richard A. Matasar, The Viability of the Law Degree: Cost, Value, and Intrinsic Worth, 96 Iowa L. Rev. 1579, 1627-28 (2011) ("Schools will diversify, stratify, cooperate, accelerate, and disaggregate in the quest for high quality and lower cost. As in every other industry, legal education needs to be bigger, better, cheaper, and faster.").

${ }^{23}$ Scott Flaherty, Legal Industry Outpaces US Jobs Figures for December, AM. LAW. (Jan. 6, 2017), http://www.americanlawyer.com/topstories/id=1202776262910/Legal-Industry-Outpaces-US-JobsFigures-for-December?slreturn=20170009144802\#!.

24 The N.Y. Times, supra note 10, is one outlet contributing heavily to this narrative. 
If we take this Employment Hypothesis at face value (though there are many reasons to doubt it) as it applies to patent-bar-eligible prospective law students, it should predict a robust boom of patentbar eligible students applying to and attending law school. That is, if students went to school for the reason that obtaining the degree guarantees a job with a salary to pay off student debt in a reasonable time, MECC Engineers should be flocking to law schools. Our prior work on this topic established that the average patent attorney is busy and only getting busier ${ }^{25}$ because of the steady increase in the number of patent applications filed each year ${ }^{26}$ and the precipitous decline in the number of new entrants to the patent bar. ${ }^{27}$ Subsisting patent attorneys can demand more for their work because law firms fear the inevitable shortage of patent attorneys. ${ }^{28}$ In such a market, newly-minted patent lawyers should be negotiating higher starting salaries and subsisting patent lawyers demanding higher compensation. ${ }^{29}$ The employment outlook for patent attorneys now and in the foreseeable future is quite positive. ${ }^{30}$ Patent attorneys are busy and getting busier.

${ }^{25}$ Gone?, supra note 2, at 213.

${ }^{26} I d$. at 212.

${ }^{27}$ Id. at 197.

${ }^{28}$ See Pedram Sameni, Shortage of Patent Attorneys, LINKEDIn (July 6, 2016), https://www.linkedin.com/pulse/shortage-patent-attorneyspedram-sameni (discussing the demand for patent attorneys and larger law firms responding with increases in pay for associates).

${ }^{29}$ See Lisa Parmley, Salary Ranges for Patent Agents and Patent Attorneys, PATENT EDUCATION SERIES, http://www.patenteducationseries.com/patent-bar/salary-ranges.html, for a breakdown in patent attorney ranges, including starting salary. 
30 "From 2000 to 2014, application filings increased by an average of $5.0 \%$ per year, while the number of registered practitioners decreased by 1.4\%[.]" Kenneth L. Port et al., In Pursuit of Patent Quality (and Reflections of Reification), 20 Marq. Intell. Prop. 79, 104 (2016). Since 2014, application filings have continued to increase by an average of $1.5 \%$. U.S. Patent Statistics Chart Calendar Years 1963 - 2015, USPTO,

https://www.uspto.gov/web/offices/ac/ido/oeip/taf/us_stat.htm (last visited April 26, 2017). Since 2000, reported median patent attorney income has risen from $\$ 160,000$ to $\$ 237,000$, an average annual increase of 5.9\%. 2015 Report of the Economic Survey, AIPLA, available at http://www.aipla.org/learningcenter/library/books/econsurvey/2015E conomicSurvey/Pages/default.aspx (last visited May 8, 2017). 
Contrary to what the Employment Hypothesis predicts, however, patent-bar-eligible students are not flooding to law school. In fact, in the last decade, the number of MECC Engineers matriculating to law school declined by over $60 \% .{ }^{31}$ The number of students in most patent law classes in the U.S. has become strikingly low, compared to its peak in just 2008. ${ }^{32}$ In 2008, 830 MECC Engineers matriculated law school. ${ }^{33}$ By 2014, that number was down to 339. ${ }^{34}$ In 2015, only 335 MECC Engineers enrolled in law school, further evidencing the decline. ${ }^{35}$ This decline can be see in Graph $1^{36}$ below:

${ }^{31}$ See infra, notes 33 and 34.

${ }^{32}$ See Gone?, supra note 2, at 197.

33 The 830 number includes figures for electrical engineering (328), mechanical engineering (267), chemical engineering (127), and computer engineering (108). Undergraduate Majors of Applicants to ABA-Approved Law Schools 2008-09, L. SCH. ADMISSION COUNCIL, http://www.lsac.org/docs/default-source/data-(lsac-resources)docs/2008-09_applicants-major.pdf (last visited Mar. 7, 2017).

${ }^{34}$ This represents figures for the number of electrical engineering (114), mechanical engineering (124), chemical engineering (74), and computer engineering (27) enrolled in the 2014 to 2015 year. Undergraduate Majors of Applicants to ABA-Approved Law Schools 2014-15, L. SCH. ADMISSION CouNCIL, http://www.lsac.org/docs/default-source/data-(lsac-resources)docs/2014-15_applicants-major.pdf (last visited Mar. 7, 2017).

${ }^{35}$ In the 2015 to 2016 year, the numbers stayed similar to the previous year: electrical (110), Mechanical engineering (132), chemical engineering (72), and computer engineering (21). Undergraduate Majors of Applicants to ABA-Approved Law Schools 2015-16, L. SCH. ADMISSION COUNCIL, http://www.lsac.org/docs/default-source/data-(lsac-resources)docs/2015-16_applicants-major.pdf (last visited Apr. 15, 2018).. 


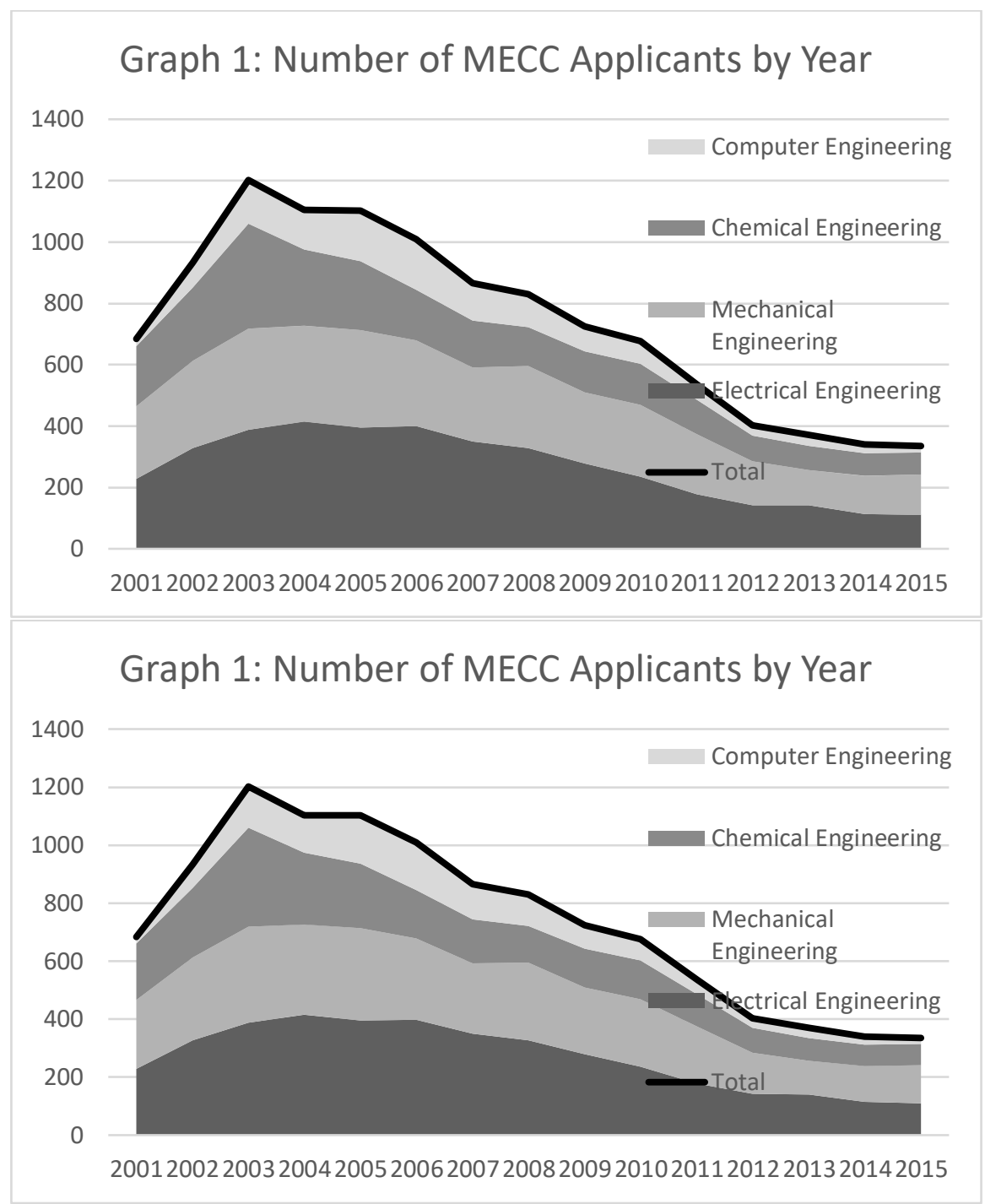

${ }^{36} I d$. 
This decrease since 2003 in the number of MECC engineers applying to law school is reflected (with a 5-year delay) in the number of new registered patent attorneys per year since 2008, shown in Graph $2^{37}$ below:

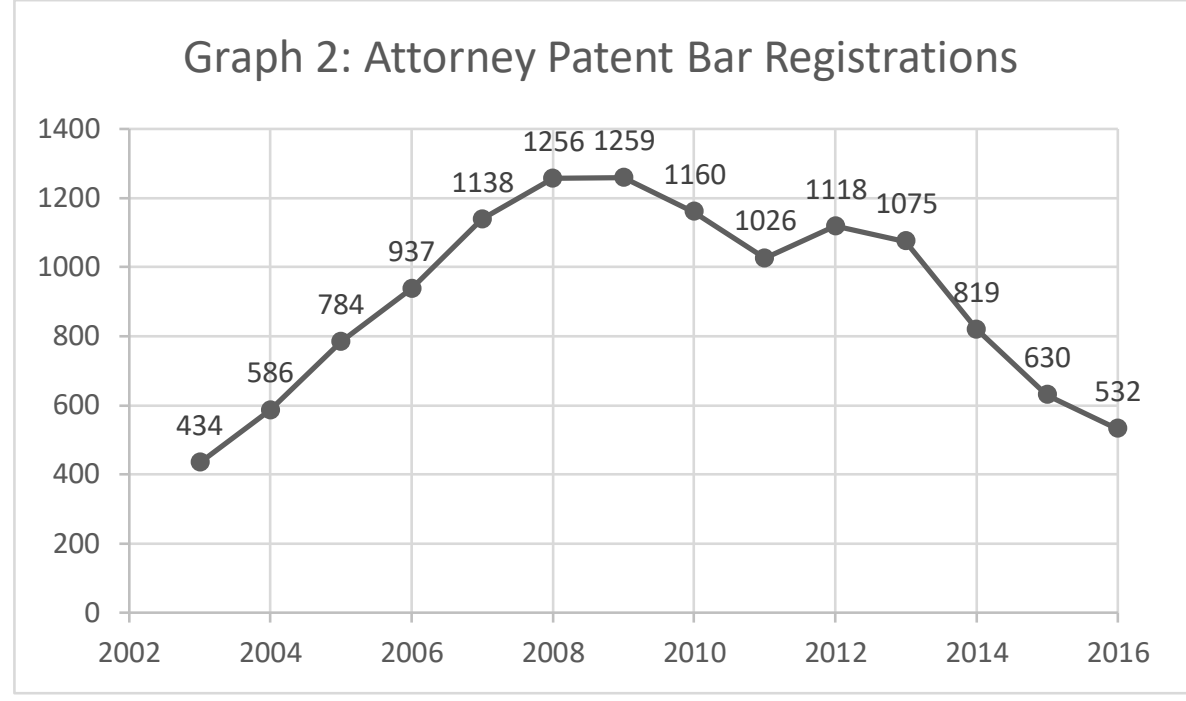

37 This data was generated based on the entire list of registered attorneys and agents available in CSV format at https://oedci.uspto.gov/OEDCI/index.jsp. The web page for each registered attorney or agent is available by using their registration number within a generalized URL, such as the author's page at https://oedci.uspto.gov/OEDCI/details.do?regisNum=72945. Dates associated with each attorney were entered into a spreadsheet and used to generate this graph. See also, Kenneth L. Port, et al., In Pursuit of Patent Quality (and Reflections of Reification), 20 MARQ. INTELL. PROP. L. REV. 79 (2016) [hereinafter Patent Quality]. 


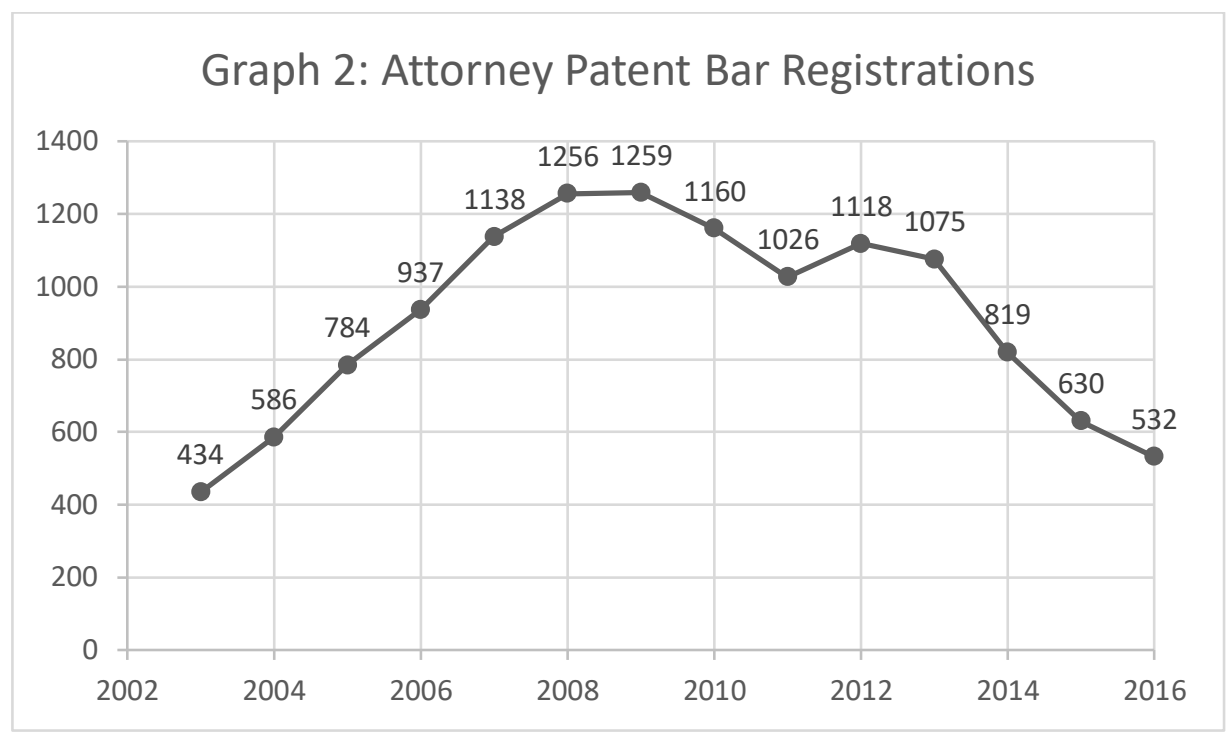

Note that there is an approximately 4-year delay between enrollment in LSAT and patent bar registration. 


\section{Patent Jobs Compared to Debt Burden}

The Employment Hypothesis suggests that if a degree does not yield maximum benefit for the degree-holder, then the prospective student will not go to law school. The staggering rate at which law school tuition is increasing leads media outlets to heavily report on tuition increases. ${ }^{38}$ Then, the theoretical leap is made that high tuition resolves to a lesser benefit for the lawyer. ${ }^{39}$ Law school is continuously identified as not being "worth it." 40 However, with the increased job prospects and higher salaries for patent attorneys, one might come to the exact opposite conclusion: that, at least for MECC Engineers, law school is very much worth it.

${ }^{38}$ Tracker, L. SCH. TRANSPARENCY, http://www.lawschooltransparency.com/reform/projects/TuitionTracker/ (last visited Apr. 22, 2017).

${ }^{39}$ See discussion supra note 10.

40 This is particularly driven by those students who are not in the top of their law school classes and cannot land the Big Law job that nets them a six-figure salary. Steven Davidoff Solomon, Law School a Solid Investment, Despite Pay Discrepancies, N.Y. TIMES (June 21, 2016), https://www.nytimes.com/2016/06/22/business/dealbook/lawschool-a-solid-investment-despite-pay-discrepancies.html. However, law school remains a good investment for these students; although these graduates may take out significant debt, the default rates on law school loans remains low. Id. 
For years, patent lawyers have been seen as thriving in the legal profession. In 2011, the NY Times suggested that "[p]atent lawyers [were] in such demand that their specialty may [have] accounted for more than 15 percent of law firm job openings while representing just 3 percent of lawyers in the United States." ${ }^{41}$ In 2013, CNN Money named patent attorney number 49 of the top 100 careers "with big growth, great pay, and satisfying work." 42 In 2014, U.S. News suggested that "[i]f you're a licensed patent attorney, then you could be hired at some $\$ 10,000$ to $\$ 15,000$ more than the $\$ 160,000$ another first-or second-year associate might be making at a large firm." 43 And, in 2017, LinkedIn ranked patent attorneys as the $16^{\text {th }}$ highest paid profession in the U.S. with a median base salary of $\$ 160,000$ per year. ${ }^{44}$ The passing of the America Invents Act in 2014 was yet another boost to the job market for patent attorneys. Because the Act requires that all papers submitted on behalf of a corporation be signed by a patent practitioner, ${ }^{45}$ patent attorneys became necessary for corporations to file patent applications. ${ }^{46}$ Similarly, the institution of inter-partes reviews, post-grant reviews, and covered business method reviews before the Patent Trial and Appeal Board ("PTAB") increased the need for patent-bar-eligible students because registered patent attorneys are the only persons eligible to argue before the PTAB. ${ }^{47}$ The AIA made patent-bar eligible attorneys integral to the patent system.

${ }^{41}$ Bloomberg News, New Law Creates a Demand for Patent Specialists, N.Y. TIMES (Oct. 9, 2011), http://www.nytimes.com/2011/10/10/business/new-law-createsdemand-for-patent-specialists.html.

42 Best Jobs in America, CNN MoNEY (2013), http://money.cnn.com/pf/best-jobs/2013/snapshots/49.html.

${ }^{43}$ Courtney Rubin, Spark Your Legal Career With These In-Demand Law Jobs, US NEWS (Mar. 12, 2014), https://www.usnews.com/education/best-graduate-schools/top-lawschools/articles/2014/03/12/spark-your-legal-career-with-these-indemand-law-jobs. 
${ }^{44}$ Ryan Sandler, The Highest Paying Jobs in America Based On LinkedIn Salary Data, LiNKEDIN (Jan. 10, 2017), https://blog.linkedin.com/2017/highest-paying-jobs-in-americabased-on-linkedin-salarydata?trk=li_corpblog_namer_careers_toppay_content\&utm_campaig $\mathrm{n}=$ toppay\&utm_source=email\&utm_content=content. Patent attorney ranked only three below "Director of Engineering" which came in at $\$ 164,000$ per year. However, $400+$ jobs were available for Director of Engineering compared to Patent Attorney's 100+ openings. 200+ jobs were open for "senior software engineering manager." Id. See also 2015 Salary Guide, ROBERT HALF LEGAL (2015), available at http://s3.amazonaws.com/DBM/M3/2011/Downloads/Salary_Guide Robert_Half_Legal_2015.pdf(“As law offices explore new business opportunities, they are on the lookout for patent attorneys with graduate or undergraduate degrees in engineering or other science-related disciples ... As a result, these professionals are seeing increased job prospects and higher compensation.”).

4537 C.F.R. 1.33 (2018); MPEP § 324 (2014).

${ }^{46}$ Dennis Crouch, AIA Shifts USPTO Focus From Inventors to Patent Owners, PATENTLY-O (Aug. 14, 2012), https://patentlyo.com/patent/2012/08/aia-shifts-usptos-focus-frominventors-to-patent-owners.html. See also David Goldman, Will Patent Reform Really Create 200,000 Jobs?, CNN MONEY (Sept. 16, 2011), http://money.cnn.com/2011/09/08/technology/patent_reform_jobs/in dex.htm.

4737 C.F.R. $\$ 42.1$ (c) (2018) (requiring lead counsel to be a registered practitioner). The Board can recognize counsel pro hac vice during a proceeding upon a showing of good cause, "subject to the condition that lea counsel be a registered practitioner and to any other conditions as the Board may impose." Id. 
Nevertheless, media outlets have continued to report on the allegedly abysmal job market for attorneys, failing to distinguish patent attorneys from the rest of the bunch. These reports claim that the reason that law school is no longer a sound investment is because the debt burden of law students is so high, and the job market so depressed, that there can be no payoff. ${ }^{48}$ We refer to this as the "perceived debt burden." According to the American Bar Association 49 ("ABA"), the average law student graduating from a state school in 2012 took out $\$ 84,600$ in student loans. ${ }^{50}$ Graduates from private law schools averaged up to $\$ 122,158 .{ }^{51}$ NPR reported in 2015 that $63 \%$ of all law students rack up more than $\$ 80,000$ in student debt, ${ }^{52}$ while on average, only $21 \%$ of all graduate-level students carry more than $\$ 80,000$ in debt. ${ }^{53}$ Others report that the cost of attending law school has nearly doubled since $2001 .^{54}$ The ABA has categorized the law school debt burden as "crushing." 55 Other sources are rating law schools by how quickly students pay off their student debt. ${ }^{56}$

${ }^{48}$ Elizabeth Olson, Burdened With Debt, Law School Graduates Struggle in Job Market, N.Y. TIMES (Apr. 26, 2015), http://www.nytimes.com/2015/04/27/business/dealbook/burdenedwith-debt-law-school-graduates-struggle-in-job-market.html; Noam Scheiber, Expensive Law degree, and No Place to Use It, N.Y.

TiMES (June 17, 2016), http://www.nytimes.com/2016/06/19/business/dealbook/anexpensive-law-degree-and-no-place-to-use-it.html.

49 The ABA self-describes as "one of the world's largest voluntary professional organizations," and is relied on as trustworthy authority regarding its data in this article and the authors' previous publications. About the American Bar Association, A.B.A., https://www.americanbar.org/about_the_aba.html (last visited May 7, 2017).

50 3YL Report, A.B.A., http://www.americanbar.org/content/dam/aba/events/law_students/a m14res-3yl.authcheckdam.pdf (last visited May 7, 2017). 
${ }^{51} \mathrm{Id}$.

52 Darian Woods, Medicine, Law, Business: Which Grad Students Borrow the Most?, NPR (July 15, 2015 12:04 PM), http://www.npr.org/sections/money/2015/07/15/422590257/medicin e-law-business-which-grad-students-borrow-the-most.

${ }^{53} I d$.

542013 Fall Average Amount Borrowed, A.B.A., available at http://www.americanbar.org/groups/legal_education/resources/statist ics.html (last visited May 7, 2017). For example, the average law student in 2001-2002 borrowed $\$ 46,499$ in public loans alone, while in 2011-2012, the average law student borrowed $\$ 84,600$. Id. In the 2012-2013 year, the question changed and the reported cost dropped to below 2001-2002 levels, with $\$ 32,289$ in public loans. $I d$.

${ }^{55}$ Minorities in the Profession Committee: Resolution, A.B.A., http://www.americanbar.org/content/dam/aba/administrative/legal_e ducation_and_admissions_to_the_bar/council_reports_and_resolutio ns/March2016CouncilOpenSessionMaterials/2016_2yl_resolution income_based_loan_repayment_cola.authcheckdam.pdf (last visited May 7, 2017).

${ }^{56}$ Ethan Baron, A New Way To Rate Law Schools: By How Quickly You Can Pay Off Your Loans, TIPPING THE SCALES (April 11, 2015), http://tippingthescales.com/2015/04/a-new-way-to-rate-law-schoolsby-how-quickly-you-can-pay-off-your-loans/. 
What these reports fail to do, however, is calculate the debt burden $^{57}$ - the actual burden of a law student after grants, scholarships, work-study, etc. ${ }^{58}$ As the reported figures are averages, most students will receive aid in some form, not all students will come away with "crushing" debt. Furthermore, not every student will be required to pay off the entirety of his or her student loans ${ }^{59}$ or be incapable of doing so. Yet, these reports bunch all law students together regardless of debt burden or job prospects, making these reports unreliable.

${ }^{57} \mathrm{We}$ acknowledge how incredibly difficult it is to obtain the net debt burden of law students in the U.S. The authors have diligently pursued these efforts but have been unable to obtain such information. The closest analysis of net debt burden the authors could find was the ABA's report: Annual Questionnaire ABA Approved Average Amount Borrowed Fall 2013, A.B.A., available at

http://www.americanbar.org/groups/legal_education/resources/statist ics.html (last visited May 7, 2017).

${ }^{58}$ An ABA report concludes that from 1991-1992 \$138,668,235 in internal grants and scholarships was awarded, while in 2012-2013 that amount jumped to $\$ 1,079,718,618$. Internal Grants and Scholarships Total Dollar Amount Awarded 1991-2012, A.B.A., http://www.americanbar.org/content/dam/aba/administrative/legal_e ducation_and_admissions_to_the_bar/statistics/internal_grants_schol arships_awarded.authcheckdam.pdf (last visited May 7, 2017).

${ }^{59}$ Some law graduates will work in the public sector and have their loans forgiven through the Public Service Loan Forgiveness Program. Public Service Loan Forgiveness Program, FEDERAL STUDENT AID, https://studentaid.ed.gov/sa/repay-loans/forgivenesscancellation/public-service (last visited Apr. 22, 2017). 
While the increase in law school tuition ${ }^{60}$ cannot be disputed, the reports do not distinguish the job markets of different legal professionals. In particular, the reports fail to acknowledge the market's need for patent bar eligible students and the increased wages accompanying that demand. The national average salary for a patent attorney is around $\$ 148,000$ per year-which is almost double the $\$ 80,000$ in student debt that $63 \%$ of law students accrue. ${ }^{61}$ Comparatively, an immigration attorney - a profession also in high demand ${ }^{62}$ — will make $\$ 88,083$ per year. ${ }^{63}$ Yet students are increasingly attending law school to pursue immigration law, while we have seen a steady decrease in patent bar eligible students. ${ }^{64}$ Despite that a patent attorney will, on average, make 55\% more a year than an immigration attorney, patent-bar-eligible students are not pursuing law like those in immigration. The question then is: if the debt burden is not a deterrent for immigration law students, why would it be one for patent bar eligible students? ROI clearly should not be a deterent for MECC Engineers to attend law school.

V. Patent Attorney Salaries Compared to Doctoral Engineering Salaries

${ }^{60}$ Law School Tuition 1985 - 2012, AMERICAN BAR AsSOCIATION, http://www.americanbar.org/content/dam/aba/administrative/legal_e ducation_and_admissions_to_the_bar/statistics/ls_tuition.authcheckd am.pdf (last visited Apr. 22, 2017).

61 The national average for patent attorneys is $\$ 148,000$. Patent Attorney Salaries, GLASSDOOR,

https://www.glassdoor.com/Salaries/patent-attorney-salary-

SRCH_KO0,15.htm (last visited May 8, 2017). See also, Noam Scheiber, An Expensive Law Degree, and No Place to Use It, N.Y. TiMES (June 17, 2016), http://www.nytimes.com/2016/06/19/business/dealbook/anexpensive-law-degree-and-no-place-to-use-it.html; Elizabeth Olson, Welcome to Your First Year as a Lawyer. Your Salary Is \$160,000, N.Y. TIMES (April 16, 2015),

https://www.nytimes.com/2015/04/17/business/dealbook/welcometo-your-first-year-as-a-lawyer-your-salary-is-160000-a-year.html. 
If these patent-bar-eligible students are not attending law school and becoming patent attorneys, but still seek to attain the highest degree in their field, they, presumably, go to school for a Ph.D. For engineers, a Ph.D. provides research opportunities within government labs and industries or tenure-track professor positions, all of which are highly competitive. ${ }^{65}$ Though there is no way to know whether these students chose a Ph.D. over a J.D., the National Science Foundation reported that in 2014 American universities awarded 54,070 research doctorates, the highest total in 58 years. ${ }^{66}$ Of all doctorates in 2014, science and engineering Ph.D.'s made up $75 \% .{ }^{67}$ Yet this same report illustrates that employment went down

62 See Delece Smith-Barrow, Pursue a J.D. for an Immigration Law, Policy Career, U.S. NEWS \& WORLD REPORT (Jan. 19 2016), https://www.usnews.com/education/best-graduate-schools/top-lawschools/articles/2016-01-19/pursue-a-jd-for-an-immigration-lawpolicy-career.

${ }^{63}$ Immigration Attorney Salaries, GLASSDOOR, https://www.glassdoor.com/Salaries/immigration-attorney-salarySRCH_KO0,20.htm (last visited May 7, 2017).

${ }^{64}$ Gone?, supra note 2, at 198.

${ }^{65}$ Devon Haynie, Choose Between a Master's, PhD in Engineering, U.S. NEWS \& WORLD REPORT (Mar. 6, 2015), https://www.usnews.com/education/best-graduate-schools/topengineering-schools/articles/2015/03/16/choose-between-a-mastersPhD-in-engineering.

${ }^{66}$ Scott Jaschik, The Shrinking Ph.D. Job Market, InSIDE HIGHER ED (Apr. 4, 2016),

https://www.insidehighered.com/news/2016/04/04/new-data-showtightening-PhD-job-market-across-disciplines.

${ }^{67}$ Doctorate Recipients from U.S. Universities, NAT'L SCI. FouND. 4 (2014),

https://www.nsf.gov/statistics/2016/nsf16300/digest/nsf16300.pdf. 
for those with a Ph.D. in engineering from $75.8 \%$ in 1994 to $66.2 \%$ in 2014. ${ }^{68}$ Those graduates employed in "industry or business" in 2014 had an average salary of $\$ 100,000$ and those in academe had an average salary of $\$ 75,000 .{ }^{69}$ Graduates with a MECC Ph.D. can expect an entry-level salary of around $\$ 100,667$, increasing to a midcareer average salary of around $\$ 139,250 .^{70}$ In contrast, patent attorneys can expect an entry-level salary of around $\$ 115,685$, increasing to a mid-career average salary of around $\$ 148,950 .^{71}$ This is summarized in the following table:

\begin{tabular}{|l|r|r|} 
Doctoral Career & $\begin{array}{r}\text { Entry-Level } \\
\text { Salary }\end{array}$ & Mid-Career Salary \\
\hline Mechanical & $\$ 81,000$ & $\$ 122,000$ \\
Engineering & $\$ 103,000$ & $\$ 144,000$ \\
Electrical Engineering & $\$ 96,100$ & $\$ 146,000$ \\
Chemical Engineering & $\$ 118,000$ & $\$ 145,000$ \\
Computer Engineering & & \\
\hline
\end{tabular}

${ }^{68}$ Table 44: Postgraduation plans of doctorate recipients with definite commitments, NAT'L SCI. FOUND., tbl.44, https://www.nsf.gov/statistics/2016/nsf16300/data/tab44.pdf (last visited May 7, 2017).

${ }^{69}$ Table 49: Median basic annual salary for doctorate recipients with definite postgraduation plans for employment in the United States, NAT'L ScI. FounD., tbl.49, https://www.nsf.gov/statistics/2016/nsf16300/data/tab49.pdf (last visited May 7, 2017). Verified

${ }^{70}$ Highest Paying PhD Majors by Salary Potential, PAYSCALE, available at http://www.payscale.com/college-salary-report/majorsthat-pay-you-back/phd (last visited May 7, 2017).

${ }^{71}$ Patent Attorney Salary (United States), PAYScAlE, available at http://www.payscale.com/research/US/Job=Patent_Attorney/Salary (last visited May 7, 2017). 


\begin{tabular}{|l|r|r|}
\hline $\begin{array}{l}\text { Average of } \\
\text { Engineering }\end{array}$ & $\$ 100,667$ & $\$ 139,250$ \\
\hline & & \\
\hline Patent Attorney & $\$ 115,685$ & $\$ 148,950$ \\
\hline
\end{tabular}

At least from a salary standpoint, a student deciding between pursuing a Ph.D. in MECC Engineer and a J.D. could be motivated by the $15 \%$ initial higher salary of a patent attorney.

However, if student debt is the deciding factor, the choice might not seem so easy. The National Science Foundation reported that in 2014 more than three-quarters of those in physical sciences and engineering reported no debt related to their graduate educated when they were awarded the doctorate. ${ }^{72}$ Research assistantships were the most important sources of financial support for physical science and engineering doctoral students in 2014. ${ }^{73}$

At first glance, a $\$ 100,000$ salary and no student debt is an enticing offer, but where a patent attorney can earn upwards of $\$ 150,000$ per year with total student debt in the $\$ 80,000$ range the difference between Ph.D income and patent attorney income is slight. Furthermore, it takes a law student three years to graduate, while it takes an engineering Ph.D. student seven years to graduate. ${ }^{74}$ If employed immediately out of law school, a patent attorney is earning an additional four years (as law school takes three years and

72 Doctorate Recipients from U.S. Universities, NAT. SCI. FOUND. 6 (2014),

https://www.nsf.gov/statistics/2016/nsf16300/digest/nsf16300.pdf (last visited May 7, 2017).

${ }^{73} I d$.

74 The median years to doctorate for an engineer in 2014 was 7.3 years. Table 31: Median years to doctorate, NAT. SCI. FOUND., tbl.31, https://www.nsf.gov/statistics/2016/nsf16300/data/tab31.pdf (last visited May 7, 2017). Verified 
a $\mathrm{Ph} . \mathrm{D}$. takes a median of seven years ${ }^{75}$ ) years of salary over an engineering doctoral graduate - a total of roughly $\$ 600,000$.

Therefore, while it cannot be the debt to salary ratio cannot be that is driving MECC engineers Engineers to forgo law school for a $\mathrm{PhD}$, an answer Ph.D., there still does not seem to exist an answer as to why students are not flocking to the patent law profession. If the Employment Hypothesis were correct as applied to patent- bareligible students, we would expect to see a far greater number of MECC engineers graduating with a J.D. than with a Ph.D.

\section{History of Ph.Ds., MBA, and All Ph.Ds.}

Not only does the Employment Hypothesis incorrectly determine how many MECC engineers we expect to see obtaining law degrees, it also creates an immense double standard: law schools are supposed to guarantee employment, while other Ph.D. programs, generally, are not. Such a high expectation exists for law schools, now that law students are beginning now becoming known to sue their law schools for failure to provide employment. ${ }^{76}$ On the contrary, graduate education subjects, by definition, merely educate the student, and do not imply that there is a specific job is waiting for the student upon graduation. ${ }^{77}$

${ }^{75} I d$.

${ }^{76}$ Olson, supra note 6; Randazzo, supra note 5; Olson, supra note 6.

77 A graduate school is "a school or division of a university or college devoted entirely to graduate studies, usually having a dean and faculty of its own, and authorized to grant advanced degrees." Graduate School, MERRIAM-WEBSTER, https://www.merriam-webster.com/dictionary/graduate\%20school (last visited May 7, 2017). 
For many years, American universities have been producing Ph.Ds. in History at a staggering pace. ${ }^{78}$ In one year, 2010-2011 alone, 1,065 people completed a Ph.D. in History at all universities in the United States. ${ }^{79}$ Presumptively, the optimal job for a person with a Ph.D. in History is that of a tenure-track professor. In 2010-11 , there were a total of 627 job openings for tenure-track, faculty jobs requiring for which a History Ph.D. was required. ${ }^{80}$ That is, if every job was filled in 2011, the employment rate for History Ph.Ds. was $59 \% .{ }^{81}$ As it seems safe to say that every single job posting did not result in a tenure-track placement, the employment rate for History Ph.Ds. in 2011 was something less than 59\%. ${ }^{82}$ Yet, there appears to be minimal conversation about the poor placement rate of History Ph.Ds., and few people claim that obtaining a Ph.D. in History it is not a wealth-maximizing choice. ${ }^{83}$

${ }^{78}$ See The American Historical Association shows consistent growth decade by decade in history Ph.Ds. Robert B. Townsend, Who Are the New History Ph.Ds.? NSF Snapshot from 2010 Provides Insights in Current Trends, AM. Hist. Ass'N (Mar. 2012), https://www.historians.org/publications-and-directories/perspectiveson-history/march-2012/who-are-the-new-history-PhDs. The American Historical Association shows consistent growth decadeby-decade in History Ph.Ds. Id.

${ }^{79}$ Table 13. Doctorate Recipients, By Subfieldr of Study: 2005--15, NAT. SCI. FOUND., https://www.nsf.gov/statistics/2017/nsf17306/datatables/tab-13.htm (last visited May 7, 2017) [[hereinafter Table 13]]. These numbers continue to climb at a steady rate - in the following years, up to 1,145 in 2015 . Id.

${ }^{80}$ Four hundred thirty-twoOnly 432 of these positions were for fulltime, tenure track positions. L. Maren Wood, What Doors Does a PhD in History Open?, , THE CHRON. OF Higher Educ. (Oct. 30, 2012), http://www.chronicle.com/article/What-Doors-Does-a-PhDin/135448/. 
Of course, for every job opening, it is not only the newly minted Ph.Ds. who apply. ${ }^{84}$ As there has been historically far fewer job openings for tenure-track positions than History Ph.D.s seeking employment Ph.Ds. produced each year, , each year some number of the backlog of Ph.D. holders also apply to those tenure-track positions. ${ }^{85}$ Again, as there is no entity that collects and reports on this data either, this is our unsupported conclusion. Further complicating the career path of the unlucky History Ph.D. holder is the fact that colleges and universities are beginning to employ nontenure-track have started employing many instructors to in something other than a tenure-track appointment in order to save money. ${ }^{86}$ These universities may save money, but they also reduce the number of Ph.Ds. in History who enter academia as a tenuretrack faculty members. ${ }^{87}$

${ }^{82}$ Although as no accrediting entity of History Ph.D. programs collects and reports on such data, this statement is merely our supposition.

${ }^{83}$ It seems, rather, that history doctorates very much know this and are resigned to the situation in general.

${ }^{84} I d$.

${ }^{85} I d$.

${ }^{86} I d$.

${ }^{87} I d$. 
Even when a newly minted History Ph.D. is lucky enough to obtain a tenure-track appointment, Glassdoor reports that the average starting salary for people with a Ph.D. in History at tenure-track positions jobs is about $\$ 50,000$ a year. ${ }^{88}$ When a J.D. holder starts a people who obtain a J.D. degree and a starting job at $\$ 50,000$ a year, the media implies that the J.D. holder has experienced this is abusive and implies that the J.D. holder is a victim of fraud from the law school they attended. ${ }^{89}$

${ }^{88}$ Professor, History Salaries, GLASsDoOR.COM, available at https://www.glassdoor.com/Salaries/professor-history-salarySRCH_KO0,17.htm (last visited May 7, 2017).

${ }^{89}$ In the aggregate, the message is that unless a new attorney secures a certain salary, his or her J.D. degree is not worth it. For example, a "J.D. Advantage" career is not considered as valuable as one requiring a J.D. 
As such, many History Ph.Ds. do not last long in the profession for which they educated themselves and, often, went into debt to become educated. As in law, it is difficult to obtain statistics on the number of people who abandon the very profession for which they obtained an education. ${ }^{90}$ Nonetheless, we can almost be positive that the number is not zero. Many people start down the academic road only to give it up when they fail to make enough money to support a family or other desired lifestyle. ${ }^{91}$ One study of four top-ranked History Ph.D. programs found that only 50.6 percent $4 \%$ of alumni wound up in a permanent, tenure-track teaching job. ${ }^{92}$ The balance of people who have obtained a Ph.D. in history go on to work in industry, administration, non-tenure track education, and the like. ${ }^{93}$ If $50 \%$ of people graduating from law school never found a job as a lawyer, what havoc would the media rain down on law schools? As is, in the most depressed market law has ever found itself, by 2014, three- quarters of the 2010 law graduates were employed in a job requiring a JD. ${ }^{94}$ Because of the number of under-employed history PhDs in 2014. ${ }^{95}$ That is, at least compared to History, the claim that there is an oversupply of lawyers seems spurious. There is a remarkable oversupply of History Ph.Ds. and not a word is uttered about this fact in the media. ${ }^{96}$ It appears that the media has played a role in creating the crisis in law school enrollment and now they are reporting on the crisis that they made themselves.

${ }^{90}$ One study states, while supporting the claim here that although roughly 50 percent\% of $\mathrm{PhD}$ holders are working in tenured or tenure-track jobs and, further claims that most historyHistory $\mathrm{PhD}$ holders are gainfully employed, but lists some 25 percent of $\mathrm{PhD}$ holders are employed \% as "other,"” employed further supporting the conclusion here that there is little data to be had regarding careers outside of academia. L. MAREN WOOD \& ROBERT B. TOWNSEND, The MANy CAREers of History PhDs: A Study of Job OutCOMES 8 ((Spring 2013), https://www.historians.org/jobs-and-professionaldevelopment/career-diversity-for-historians/career-diversityresources/the-many-careers-of-history-phds.

91 Wood, supra note 90. 
${ }^{92} I d$. at 2.

${ }^{93} I d$. at 2,5 .

94 Deborah Jones Merritt, What Happened to the Class of 2010? Emperical Evidence of Structural Change in the Legal Profession 2015 MICH. ST. L. REV. 1043, 1083.

${ }^{95}$ In the worst depressed market for lawyers we have ever seen, another study points out that $75 \%$ of the graduates from 2010 were employed in jobs requiring a JD in 2014. See Deborah Jones Meritt, 2015 MICH. ST. L. REV. 1043, 1083.

${ }^{96}$ See generally, Laura McKenna, The Ever-Tightening Job Market for Ph.D.s, THE ATLANTIC (Apr. 21, 2016), https://www.theatlantic.com/education/archive/2016/04/bad-jobmarket-phds/479205/ (noting that although many "newly minted" PhDs are "without the promise of a job .... few people seem to be paying attention to these findings"). 


\section{a. MBA}

Recent data shows that the average starting salary for graduates of the top U.S. MBA programs is to be around $\$ 146,000$, compared to an average education debt of around $\$ 106,000 .{ }^{97}$ In contrast, the average salary for top law programs is around $\$ 166,155$, with an average indebtedness of around $\$ 140,900 .{ }^{98}$ There are significant differences between these two programs, however the return on investment is less stark. For both the top MBA programs and top law programs, if each graduate applied half of his or her salary toward debt, the graduate would have paid off their debt in less than two years. ${ }^{99}$ Even for Florida Coastal School of Law, which consistently has the lowest ratio of average salary to average debt, the repayment period at half- salary would still be less than four years. ${ }^{100}$

${ }^{97}$ Briana Boyington, See the Average Debt, Starting Salaries for MBA Grads at Top B-SchoolsBusiness School Graduates, U.S. NEWS \& WORLD REP. (July 20, 2016), https://www.usnews.com/education/best-graduate-schools/topbusiness-schools/articles/2016-07-20/see-the-average-debt-startingsalaries-for-business-school-graduates.

${ }^{98}$ See generally, 2017 Law School Rankings: What You'll Earn (and What You'll Owe), SoFi Return on Education, https://www.sofi.com/blog/sofi-2017-law-school-rankings/ [[hereinafter SoFi's]]. As stated in the report, "The data was gathered from over 60,000 applicants for SoFi student loan refinancing between January 1, 2014 to December 28, 2016. Individuals were divided into degree category cohorts that reflect their graduate degree program. The figures shown in the Law School analysis are based on a pool of applicants who reported receiving a Law degree and who have, on average, three years of work experience since graduation. Degrees and salary are self-reported and are only verified at the underwriting stage if a loan is approved.

${ }^{99}$ For MBA programs, $\$ 106,000 /(\$ 146,000 / 2)=1.45$ years; for law, $\$ 140,900 /(\$ 166,155 / 2)=1.70$ years. 
More importantly, those that study MBA programs have concluded that, economically, one may be better off staying put and rising through the corporate ranks rather than disrupting one's life, taking on six figure debt, and spending two years out of the job market. ${ }^{101}$ MBA programs are proliferating. Although the employment prospects are good, economists have concluded that an pursuing an MBA is not a non-wealth-maximizing endeavor for anyone who is currently adequately employed. ${ }^{102}$ And still, there is no media outcry about the value, the debt burden, the disruption, or cost of removing oneself from the job market for two years. The media, if were fair and balanced, seems to need to report on the job prospects, ROI, and career paths of all professionals, not just JD holders.

$100 \$ 158,427 /(\$ 84,664 / 2)=3.74$ years. See Sofi's, supra, note 98.

${ }^{101}$ See Shawn O'Connor, When Is anAn MBA Worth It-When Is It Not?, PoETs \& QuANTS (June 27, 2011), http://poetsandquants.com/2011/06/27/when-is-an-mba-worthit\%E2\% 80\%94when-is-it-not/.

102 Philip Delves Broughton, Think Twice, THE ECONOMIST, http://www.economist.com/whichmba/think-twice (last visited May 7, 2017);

Ashley Stahl, Ten Reasons You Don't Need An MBA, FoRBES (Feb. 2, 2016), https://www.forbes.com/sites/ashleystahl/2016/02/02/tenreasons-you-dont-need-an-mba/\#5b1f9a1147d6.; Philip Delves Broughton, Think Twice, THE ECONOMIST, http://www.economist.com/whichmba/think-twice (last visited May 7, 2017). 


\section{b. All Ph.Ds.}

The overall employment picture for all $\mathrm{PhD}$. $\mathrm{Ph} . \mathrm{Ds}$. is quite negative and still, many people are encouraged to obtain a Ph.D. degree. The Atlantic reports that nearly $45 \%$ of all Ph.D. recipients did not have employment upon graduation even though it took them roughly 10 years to obtain the degree. ${ }^{103}$ That is, the median Ph.D. recipient had ten years to plan for their graduation and they still failed to secure employment by that time. This failure to secure employment refers to any employment, not just academic employment. In 1987, roughly 32,000 Ph.Ds. were awarded in the United States. By 2014, that number had grown to 54,000 or an increase of $60 \%$ in under 30 years. The American society is becoming hyper-educated ${ }^{104}$ but not hyper-employed. ${ }^{105}$

103 See McKenna, supra note 96.

${ }^{104}$ See Table 13, supra note 79. The Humanities and arts, over the last ten years, have been consistently produced between 4,700 and 5,000 doctorate graduates a year. Doctorate recipients, by subfield of study: 2005-15, NAT. SCI. FOUND., https://www.nsf.gov/statistics/2017/nsf17306/datatables/tab-13.htm (last visited May 7, 2017).

105 See McKenna, supra note 96 (claiming that 40\% of Ph.D. recipients are never employed or are in jobs completely unrelated to their field). 
Regarding Humanities Ph.Ds. specifically, The Atlantic report analyzed Ph.D. graduates' attempts to secure a job outside of academia. The report concluded conclusion was that employment outside of academia is nearly impossible to track as "most doctoral programs have never systematically tracked the employment outcomes of their Ph.D a [sic]."106 If there is no tracking of data of employment outside of academia and over half of humanities $\mathrm{Ph} . \mathrm{Ds}$. are employed in jobs outside of academia, it may not be surprising that there is no complaint from the media regarding employability of humanities Ph.Ds. That is, in order to comment on this, one would have to collect the data. To collect the data, one would have to have the cooperation of every humanities Ph.D. program in the United States. The most appropriate entity to collect this data is the body that accredits humanities Ph.Ds. However, these entities do not seem to collect and make public employment data.

This begs the question of what would happen to humanities Ph.D. enrollment if this data were collected, reported, and commented on, as it is with law. This leads to one possible conclusion that the problem with law school enrollment and MECC Engineer enrollment in law school specifically is that the ABA (the accrediting authority of law schools) requires that law schools collect and report on employment statistics. It may be the mere transparency of law schools that leads to negative decisions about enrolling. With no data, humanities Ph.Ds. blithely blunder along, ignorant of their employment chances.

${ }^{106}$ Elizabeth Segran, What Can You Do With a Humanities PhD, Anyway?, The Atlantic (Mar. 31, 2014), http://www.theatlantic.com/business/archive/2014/03/what-can-youdo-with-a-humanities-PhD-anyway/359927/. 
Comparing patent law to these other specific fields, the Employment Hypothesis becomes increasingly tenuous. Individuals who possess both an MECC degree and a JD degree fare far better than others with a law degree or even the other fields compared here. MECC majors comprise $73.5 \%$ of all patent attorneys. ${ }^{107}$ That is, MECC degree holders are real success stories of law schools. However, in 2015, 324 individuals matriculated any law school compared to $361^{108}$ just two years earlier ${ }^{109}$ or a decline of some $11 \%$ in two years. This decline coincided with an increase in patent filing, ${ }^{110}$ a remarkable increase in the number of MECC Engineers obtaining a Ph.D., ${ }^{111}$ and a reported increase in innovation and technical orientation in the United States. ${ }^{112}$ In a decade, the decline of MECC Engineers who attend law school exceeds $60 \% .{ }^{113}$ Truly, if the Employment Hypothesis had any merit, no one has told MECC Engineers. There are significant patent job opportunities for MECC Engineers and still they do not attend law school. ${ }^{114}$ Instead, MECC Engineers obtain Ph.D. degrees in their fields in healthy numbers.

${ }^{107}$ Ralph D. Clifford, Thomas G. Field, Jr., \& Jon R. Cavicchi, A Statistical Analysis of the Patent Bar: Where are the Software-Savvy Patent Attorneys?, 11:223 N.C. J. OF L. \& TECH. 260-261 (Spring 2010). The cumulative grouping for the top majors of patent bar members are $26.0 \%$ chemical, $25.4 \%$ mechanical, $17.6 \%$ electrical, and $4.5 \%$ computer. $I d$.

108 Under Majors of Applicants to ABA-Approved Law Schools: Applicants by Major: 2015-2016, A.B.A., http://www.lsac.org/docs/default-source/data-(lsac-resources)docs/2015-16_applicants-major.pdf (last visited Apr. 23, 2017). 
${ }^{110}$ Patent applications are expected to grow at 3-5\% over the next five years, a trend that shows consistent, but slower, growth than the $4.9 \%$ growth that the USPTO predicted in previous years. Compare UNITED STATES PATENT AND TRADEMARK OFFICE FISCAL YEAR 2012 PRESIDENT'S BUDGET (Feb 14, 2011), available at https://www.uspto.gov/sites/default/files/about/stratplan/budget/fy12 pbr.pdf with USPTO, FISCAL YEAR 2017 PRESIDENT'S BUDGET: THE USPTO CONGRESSIONAL BUDGET JUSTIFICATION 15 (Feb 2, 2015), available at https://www.uspto.gov/sites/default/files/documents/fy17pbr.pdf. 111 The MECC fields received a dip in Ph.Ds. at the time of the great recession but their increase returned to a more expected pace in the aftermath.

112 Except for a decrease in patent applications in 2009, United States applications have been on an upward increase for at least the last decade. Statistical Country Profiles: United States of America, WORLD INTELL. PROP. ORG., http://www.wipo.int/ipstats/en/statistics/country_profile/profile.jsp?c ode $=$ US (last visited May 7, 2017). WIPO reports that global patents rose in 2015, up 7.8\% from 2014 applications. Global Patent Applications Rose to 2.9 Million in 2015 on Strong Growth From China; Demand Also Increased for Other Intellectual Property Rights, WORLD INTELl. PROP. ORG. (Nov. 23, 2016), http://www.wipo.int/pressroom/en/articles/2016/article_0017.html.

113 Under Majors of Applicants to ABA-Approved Law Schools: Applicants by Major: 2005-2006, A.B.A., http://www.lsac.org/docs/default-source/data-(lsac-resources)docs/2005-06_applicants-major.pdf. 
${ }^{114}$ For example, "entry-level salary for a good software engineer is easily in six figures in most major US cities.” Pedram Sameni, Patexia Chart 1: Shortage of Patent Attorneys, PATEXIA (Jul. 6, 2016), https://www.patexia.com/feed/shortage-of-patent-attorneys20160706. Since it would cost 100,000 or more to attend law school for many applicants, the investment in a law degree for a patent law position at a later date is seen as simply not worth the investment. Id. 


\section{Law Compared to Other Graduate Degrees}

A further corollary to the Employment Hypothesis is that it demands or expects $100 \%$ employment from law school graduates in full-time jobs requiring a law degree; however, this has never been remotely related to reality. Law has never been a guarantee to a fulltime job requiring a law degree. ${ }^{115}$ In fact, historically, law is doing, statistically, about the same job as it ever has in assisting law graduates to find full-time employment which requires a law degree. ${ }^{116}$ Excluding periods of economic recessive activity, ${ }^{117}$ graduates with a degree in law have been employed four years after their graduation ${ }^{118}$ at about $85-90 \%{ }^{119}$ for the last two decades. We have never seen the employment rate of law graduates to be anywhere near $100 \%$ four years after their graduation. ${ }^{120}$ It is irrational for the Employment Hypothesis to perpetuate the expectation of $100 \%$ employment. The media's role accentuates this expectation. As a result of this expectation, it appears that MECC Engineers overwhelmingly decide to obtain a Ph.D., rather than a J.D. ${ }^{121}$

This begs the question: why does our society hold law to this different standard? Why now? Why did the employment hypothesis take such a hold on the legal community? Why do we now care so much about the placement rate of law graduates when no other graduate degree program seems to give it much thought to it at all? 
115 There is at least a 100 year-long debate about whether we are educating people to be lawyers or educating people to get, essentially, a $\mathrm{PhD}$ in liberal arts. Some argue that law schools are meant to train lawyers for private practice. John Lande, Reforming Legal Education to Prepare Law Students Optimally for Real-World Practice, 2013 J. DisP. RES. 1, i; Bronner, supra note 3 (citing USC professor's suggestion that "big corporations [are] dissatisfied with what they see as the overly academic training at elite law schools."); David Segal, What They Don't Teach Law Students: Lawyering, N.Y. TIMES, Nov. 20, 2011, at Al; see also WILLIAM M. SULLIVAN ET AL., THE CARNEGIE FOUND. FOR THE ADVANCEMENT OF TEACHING, EDUCATING LAWYERS: PREPARATION FOR THE PROFESSION OF LAW (2007) (suggesting that law schools should integrate more practical and ethical training into their curricula, alongside legal analytic training). Some claim that law schools should be more like the other academic disciplines and mainly hire $\mathrm{PhD} / \mathrm{JD}$ people from the social sciences; Christopher Edley, Jr., Fiat Flux: Evolving Purposes and Ideals of the Great American Public Law School, 100 CALI. L. REV. 313, 315, 318 (202) (noting trend toward cross-pollination with other disciplines and suggesting that the modem law school has been "enriched by diverse, PhD-trained faculty"); see also David Van Zandt, Discipline-Based Faculty, 53 J. LEGAL EDUC. 332, 335 (2003) (in an earlier era, arguing in favor of hiring "academics with a strong disciplinary training in one of the social sciences ... who are also well-trained lawyers."). Of course, this is a false choice. Law schools have always taught both the theory and practice of law. Benjamin Spencer, The Law School Critique in Historical Perspective, 69 WASH. \& LEE REV. 1949, 1956-58 (2012) (suggesting that the critique that law schools are not sufficiently practice-oriented has been heard for the past 130 years and noting that both missions can coexist); see also Kristen Holmquist, Challenging Carnegie, 61 J. LEGAL EduC. 353, 354 (2012) ("In 1933, Jerome Frank famously called for transforming 'law schools' into 'lawyer schools."'). 
${ }^{116}$ Over the course of the last 20 years, the employment rate has remained between the mid- $80 \%$ to the lower $90 \%$ for of the graduating class whose employment status was known. James G. Leipold, et al., The Stories Behind the Numbers: Jobs for New Grads Over More Than Two Decades, NAPL BulLETIN (Dec. 2016), http://www.nalp.org/1216research.

117 The Great Recession in the U.S. economy began December 2007 and ended in June of 2009. Business Cycle Dating Committee, NAT. BurEAU OF ECON. RES. (Sept. 20, 2010), http://www.nber.org/cycles/sept2010.html. From 1994-2015, the average rate of lawyers employed when the employment status was known was $88.91 \%$. See Leipold, supra note 116 . Even excluding 2010 through the present, the average improves only to $90.01 \%$. See id.

118 The time period of four years out from graduation, rather than in the immediate year following commencement, is drawn from Deborah Jones's research examining the population of 1,214 lawyers admitted to the Ohio bar in 2010, in which she notes that from 200105 saw a marked improvement in employment compared to 2001-02 employment figures. This allows for time for the job market to stabilize. Deborah Jones, What Happened to the Class of 2010? Empirical Evidence of Structural Change in the Legal Profession, 2015 MicH. L. REV. 1043 (2015).

${ }^{119}$ See Leipold, supra note 116.

${ }^{120}$ See id.

${ }^{121}$ See supra V. 


\section{What explains the dearth of MECC engineers attending Law School?}

Though the employment hypothesis offers some suggested explanations, no one knows precisely what specific factors lead MECC Engineers away from patent law. There is no organization or agency that collects national data on the career trajectory of MECC Engineers. However, after studying this issue for several years and writing three articles on this topic, we would like to propose several hypotheses that may explain the current dearth in MECC Engineers and what lead to this precipitous decline. These hypotheses include the following: 1) The practical vs. elite narrative confuses rational MECC Engineers and they elect not to enter law school; 2) MECC Engineers may be obtaining Ph.Ds. instead of going to law school; 3 ) the psychological theory of bandwagoning may explain the dearth of MECC Engineers in law school; 4) the fact that law lacks a grand theory may discourage MECC Engineers from going to law school; and/or 5) incentives are not in place to encourage MECC Engineers to obtain a law degree and become patent lawyers. ${ }^{122}$

122 Of course, as hypotheses, what follows are thoughts that can and should be proven or disproven by us or others in subsequent work. 


\section{a. Hypothesis One: The practical vs. elite narrative is a disjointed disincentive}

It may be that law schools inadvertently suppress MECC Engineer numbers because they claiming they are "practical."123 Many law schools trip over themselves to claim that one school is more practical than another. ${ }^{124}$ "Theoretical" law schools are sometimes viewed by practical law schools with disdain. ${ }^{125}$ Many professors from practical schools consider theoretical schools to be too conceptual to provide a meaningful law-based education; ${ }^{126}$ theoretical schools call themselves "elite" 127 and sometimes think that practical law schools are just teaching students how to be highpaid scriveners. ${ }^{128}$ Of course, this distinction between elite and practical is a claim based, mostly, on one magazine's self-asserted opinion, not on objective fact. ${ }^{129}$

${ }^{123}$ Of the 20 law schools listed as the "Best Schools for Practical Training" by the National Jurist, 8 of 20 had the mention of "practical" somewhere on their website, usually on the "Mission," "About," or very front pages. Best Schools for practical training: 2015, ThE NAT. JuRIST (Feb. 6, 2015), http://www.nationaljurist.com/content/best-law-schools-practicaltraining-2015.

${ }^{124}$ St. Thomas School of Law states, for instance, that they have "earned top rankings nationally" for their "professors, practical training, clinical programs, externships, and quality of life." ST. THOMAS SCHOOL OF LAw, http://www.stthomas.edu/law/ (last visited Jan. 25, 2017 at 12:55 PM). Baylor touts its listings as one of the "Best Schools for Practical Training." Nick Teixera, Baylor Law Listed a 'Best School for Practical Training' and 'Best School for the Devout', BAYLOR L. NEWS (Apr. 18, 2016), http://www.baylor.edu/law/news.php?action=story\&story $=168007$. Or Florida Coastal Law, which touts its place on the "honor roll of best schools in practical training." About Us, FLORIDA COASTAL L., http://www.fcsl.edu/about-coastal-law.html (last visited Apr. 16, 2017). 
${ }^{125}$ Robin West, The Contested Value of Normative Legal Scholarship, 66 J. LEGAL EDUC. 6, 6-7 (2016)

http://tippingthescales.com/2014/05/theory-vs-practice-how-schoolsshould-teach-law/. Judge Finesilver wrote in 1977 that this leads to the feeling that the theoretical "law school experience is both unrealistic and irrelevant." Sherman G. Finesilver, The Tension Between Practical and Theoretical Legal Education: A Judge's View of the Gap, Buy. L. Ref. 1061, 1062 (1977).

${ }^{126}$ Similarly, law school faculty sometimes looks down on the concept of a law school as a trade school with similar condemnation. Sherman G. Finesilver, The Tension Between Practical and Theoretical Legal Education: A Judge's View of the Gap, 1977 BYU. L. REF. 1061, 1064 (1977).

127 Yale advertises itself as offering "cutting-edge legal theory." Admissions, YALE L. SCH., https://www.law.yale.edu/admissions (last visited May 7, 2017). "Elite" seems somewhat out of style, at least from looking over the admissions pages of Yale, Harvard, and Stanford, the top three "Best Law Schools" by US News \& World Report. Best Law Schools, U.S. NeWS \& WORLD REP., https://www.usnews.com/best-graduate-schools/top-lawschools/law-rankings?int=a1d108 (last visited May 7, 2017).

${ }^{128}$ Certainly, this seems to be the view of Justice Antonin Scalia. See Maya Itah, Theory vs. Practice: How Schools Should Teach Law, TIPPING THE SCALES (May 24, 2014), http://tippingthescales.com/2014/05/theory-vs-practice-how-schoolsshould-teach-law/. 
129 Jeffrey Evans Sake, The Interplay Between Law School Rankings, Reputations, and Resource Allocation: Ways Rankings Mislead, 81 Ind. L.J. 229, 231(2006) ("But law school rankings are not presentations of data or other facts. Law school rankings are opinions. It is the opinion of the editors at U.S. News that Yale is the best law school. The editors are forthright-unusually and surprisingly forthright-in their presentation of the mechanical calculations that lead them to their opinion."). In fact, the American Bar Association, the accrediting organizations for law schools, has the following disclaimer about ranking law schools on the main page of their website:

No rating of law schools beyond the simple statement of their accreditation status is attempted or advocated by the official organizations in legal education. Qualities that make one kind of school good for one student may not be as important to another. The American Bar Association and its Section of Legal Education and Admissions to the Bar have issued disclaimers of any law school rating system. Prospective law students should consider a variety of factors in making their choice among schools.

American Bar Assocaition, ABA Approved Law Schools, https://www.americanbar.org/groups/legal_education/resources/aba_ approved_law_schools.html (last visited July 19, 2017). 
These rankings and the resulting perceptions that one school is better than another school exists even though there is no objective evidence that any one law school is much different from any other. Most law professors in the United States attended one of a very small number of law schools. ${ }^{130}$ In fact, one study showed that of the top-ranked 34 law schools, there were 1,486 tenured or tenuretrack professors of law. Of those 1,486 professors, 396 graduated from Harvard Law School (22.6\%), 380 graduated from Yale Law School (21.7\%), and 110 graduated from University of Chicago Law School (6.3\%). ${ }^{131}$ That is, 886 or nearly $60 \%$ of law faculty in the 34 highest "ranked"132 law schools in the United States attended one of three law schools, indicating that many law students were educated by the same type of class of law professors.

130 The factor most important for receiving a call-back interview for a tenure-track position was if the candidate graduated from a top-50 law school. Tracey George and Albert Yoon, The Labor Market for New Law Professors, J. OF EMPIRICAL STUD., 7 (2013). The highest contenders there were Yale, Harvard, and Stanford. Id. $62 \%$ of entrylevel law professor applicants in 2007-08 were from Tier 1 schools. Id. at 23.

${ }^{131}$ Justin McCrary, Joy Milligan, and James Phillips, The PhD Rises in American Law Schools, 1960-2011: What Does It Mean for Legal Education? 65 J. LEGAL EDUC. 543, 554 (2015-2016).

${ }^{132}$ For example, the first year courses for J.D. programs at Chicago, Cornell, and NYU all include Civil Procedure, Constitutional Law, Contracts, Criminal Law, and Property. See, e.g., http://www.law.uchicago.edu/prospective/1lcourses, http://www.lawschool.cornell.edu/admissions/admitted/first_year.cf $\mathrm{m}$, http://www.law.nyu.edu/academics/courses/requiredfirstyearcourses. 
Despite these rankings, there is little variation in legal curricula among law schools of various rankings. Every law student studies the same topics as every other law student in the United States using the same or very similar textbooks. ${ }^{133}$ Every law professor talks about the same things in every relative law school class. Some schools reward their professors for only writing conceptual material that gets published in law reviews with tenure; ${ }^{134}$ some schools reward professors who write other material such as jury instructions, hornbooks, textbooks, and the like. Some professors write a lot; some professors write very little. Some even claim that all professors are of the elite variety. ${ }^{135}$

${ }^{133}$ If one compares the content of the Carolina Academic Press' Property textbooks, the Copyright textbooks, or the Trademark textbooks, one sees the point. There is remarkable overlap between the various texts on any given subject. http://www.cappress.com/books/subject/7. Of course, emphasis and focus changes by book but the heart of the cases is remarkably consistent. In addition, if one compares the First Year curriculum of one law school to the First Year curricula of other law schools, there is remarkable overlap. NYU:

http://www.law.nyu.edu/academics/courses/requiredfirstyearcourses. Berkeley: https://www.law.berkeley.edu/academics/jd/first-yearcurriculum/. Harvard: http://hls.harvard.edu/dept/jdadmissions/whyharvard/academics-scholarship/curriculum/. Duke:

https://law.duke.edu/curriculum/firstyr/. Mitchell Hamline:

http://mitchellhamline.edu/students/academic-planning-module-icurriculum-overview/. Comparing law schools more generally, the point is even more obvious: https://www.princetonreview.com/lawschool-advice/first-year-curriculum.

${ }^{134}$ One estimate found that pre-tenure law professors published 44.5 pages a year. Jeffrey L. Harrison, Post-Tenure Scholarship and Its Implications, 17 U. FLA. J.L. \& PUB POL'Y 150 (2006). Posttenure, this rate dropped down to 30 published pages a year. $I d$. 
${ }^{135}$ Kenneth W. Starr, Legal Education at the Threshold of the New Millenium: Keynote Address, 15 J. CIV RIGHTS ECON DEV. 253 ("The nature of the law school itself. Over the past generation, it seems to me that we have seen the emergence of the truly academic faculty in most law schools all around the country. Simply stated, the current belief in many law schools is that the law faculty should, above all, consist of scholars and teachers and not necessarily those who have been steeped in the profession itself. In fact, in many schools, as we know, too many years of practice and experience in the profession, could actually be viewed as a mark against one's likelihood of success in moving into the academy"). See James R. P. Ogloff, Annual Nebraska Survey \& Survey of Legal Education: More Than "Learning to Think Like a Lawyer": The Empirical Research on Legal Education, 34 CREIGHTON L. REV. 73, 131-32 (2000) (stating that tendency to hire law professors with practical experience is most evident in lower level law school, as opposed to more elite law schools, implying that as to elite law schools, professors are not encouraged to receive practical experience). 
Yet, law professors accept this narrative that was created by US News and World Report to sell magazines. US News provides factors (that unsuspecting readers foolishly believe are objective) that prospective students can use to discern the difference from one law school to another. ${ }^{136}$ These determinations are relied upon by prospective students, deans, professors and the media to come to the conclusion that one school is "better" than another. ${ }^{137}$ Regardless of whether there are differences in these law schools' curriculums, ${ }^{138}$ US News creates a grand distinction among schools where there is basically none.

${ }^{136}$ Robert Morse \& Kenneth Hines, Methodology: 2018 Best Law Schools Rankings, U.S. NEWS \& WORLD REP. (Mar. 19, 2018), http://www.usnews.com/education/best-graduateschools/articles/law-schools-methodology?int=9d0608.

${ }^{137}$ Reputations of law schools tend to be geared more toward the front-end; those choosing a law school will depend on US News, as do law school faculty and administrators. Jeffrey Evans Stake and Michael Alexeev, Who Responds to U.S. News \& World Report's Law School Rankings? 12 J. OF EMPIRICAL LEGAL STUD. 421, 477 (2015). However, this mainly affects lower-ranked schoolsparticularly those that are cracking the top 40 slots for the first time. Id.

138 This These distinctions may be meaningful to some students. For example, some universities allow many credits from one school to be applied to a JD, even though those credits might be rather immaterial to a law degress. Or some law schools allow or mandate a certain number of credits be taken for clinical experiences or "experiential learning." This should not fool anyone that, at their core, the ABA mandates that each law school is more or less the same. 
Although law professors are frequently criticized for either not doing empirical research ${ }^{139}$ or not doing it correctly ${ }^{140}$ as viewed by statisticians, the disconnect between reality and the narrative created by US News could not be more stark. Law schools are all, at their core, essentially the same or very similar. In such an environment, competitors (in the form of law schools) naturally seek to distinguish themselves from one another. If you are on the losing end of the US News narrative, you naturally seek other distinguishing characteristics. Many law schools have lost out on the US News "elite" narrative and, instead, have substituted it with the "practicality" narrative.

Naturally, when comparing elite to practical law schools, all lose sight of the fact that every graduate, whether from a self-proclaimed elite law school or a self-proclaimed practical law school, must pass the exact same bar examination to become an attorney and by extension a patent attorney. That is, it does not matter if a student went to a practical law school or a theoretical law school-all students have to pass the same exam if they want to practice law.

Owing to the consistency among law school curricula, the degree to which a specific law school is actually more or less practical than any other law school is unclear. However, the practicality narrative itself has unintended consequences. The purpose of the practicality narrative was to give prospective students a measure to compare law schools where one set of law schools comes out on top compared to another set of law schools, again, even though there are nondemonstrated objective differences among the practicality of various law schools. That is, the practicality narrative is an artificial construct, similar to the ways in which the US News law school ranking narrative is an artificial construct.

139 Carl E. Schneider \& Lee E. Teitelbaum, Life's Golden Tree: Empirical Scholarship and American Law, 2006 UTAH L. REV. 53, 58 (2006).

${ }^{140}$ See, e.g., Lee Epstein and Gary King, The Rules of Inference, 69 U. CHI L. REV. 1 (2002). 
However, once a large number of law schools go down the practicality narrative road, it is difficult for any law school to turn back. To claim a law school is practical is to claim that there is a higher point to attending that law school. That higher point is to prepare you to get a job doing one certain thing - being a lawyer. If a law school claims to be practical, it is making some sort of statement about its ability to place all of its students in the legal job market and that the market is going to be there until they retire. That is, the point in getting a law degree becomes more synonymous to becoming a plumber. If a technical school which educates plumbers does not place a significant number (if not all) of its graduates in plumbing jobs, graduates flunk the test to become a plumber, or they are otherwise disqualified from a career in plumbing, one has to question the reason for that plumbing school's existence. Law is not a technical, plumbing degree. It is a graduate degree in liberal arts where, upon completion of the degree, some people choose to take a bar exam and some of those people elect to use that degree for a period of time to work as lawyers. This is no way a universal truth and it has never been one. A legal education provides various skills specific to the legal practice, however as it is a graduate degree in liberal arts, a legal education also teaches critical thinking and writing skills that people might use in many different ways to earn a living. Pigeon-holing all law graduates into one job and one job only invites disaster when and if that job becomes less compelling or less demanded. ${ }^{141}$

Although being a so-called practical law school is not new in the United States, ${ }^{142}$ it is new that so many law schools now claim to be practical. ${ }^{143}$ Many, if not most, law schools that are not in US News Top 20 law schools, now claim to be practical. Where they lose in the elite narrative, they attempt to win in the practicality narrative. These are convenient narratives, but they are just narratives. 
${ }^{141}$ Some are predicting a revolution in the provision of legal services with the advent of computer learning and artificial intelligence or AI where the demand for trained lawyers will go down. At least one article suggests that we may overestimate the ability of AI to provide complex legal services, but that AI may be used to provide basic legal services, which may be used to reduce the obstacles facing providing equal access to justice for all. Victor Li, "The Robot Lawyers Are Coming (to Help, Not Take Your Jobs), ABA Journal (Mar.take your jobs)," MAR 17, 2017), 04:10 PM CDT, available at http://www.abajournal.com/news/article/the_robot_lawyers_are_co ming_to_help_not_to_take_your_jobs. As patent eligible students are perceived as the most rational, it may be that they know the future better than the rest of us. They may know or sense that AI will lead to either fewer jobs or less attractive jobs or lower paid jobs and this is why they are forsaking law school at rates that far exceed non-patent eligible law students.

${ }^{142}$ Michael L. Rustad \& Thomas H. Koenig, Perspectives on Lawyer Happiness: A Hard Day's Night: Hierarchy, History \& Happiness in Legal Education, 58 SYRACUSE L. REV. 261, 288 (2008)

(claiming that in 1927, Suffolk Law School was "practical" in that it "offered specialized classes in Automobile Law, Workman's Compensation, Probate Law, the New Bankruptcy Federal Code, Practical Conveyancing, Accounting, Income Tax, Equitable Estates, and Massachusetts Land Court Procedure to assist its law graduates in practice and prepare them for the bar examination. A number of night law schools throughout the country adopted Archer's pedagogy. Atlanta Law School and a new law school in Milwaukee adopted the Suffolk Method of law school instruction in 1925)..). In fact, when NYU, in a former incarnation, attempted to make a "purely practical" law school to supplement an education in law, it lasted but two years. See also Andrew M. Siegel, Note: "To Learn and Make Respectable Hereafter”: The Litchfield Law School in Cultural Context, 73 N.Y.U.L. REV. 1978 (1998) 
However, the practicality narrative is a narrative with a consequence. When all or substantially all law graduates do not place in jobs requiring a law degree, the system appears to have totally failed. If you say you are a practical law school, you are saying that you have a stake in reality, a stake in the students' future, a stake in students' ability to make a living. A practical law school's reason for existence is to guarantee its graduates work as lawyers in established law firms. This is a perceived reality based on a fictitious narrative. Therefore, just because a practical law school disclaims responsibility to place its graduates, students perceive a duty on the part of the practical law school to see them employed. If a practical law school's graduates do not find employment in such a circumstance, one has to question the reason for that law school's existence. The primary purpose of practical law schools' existence is frustrated. When the primary purpose is apparently frustrated, there should be no surprise that prospective students elect to do something else with their time and money.

Patent-eligible students may hear the practical narrative, take it literally, and expect every patent-eligible graduate to be placed as a patent attorney. But they still do not come to law school because of the conflicting narratives that they hear. While hearing that practical law schools provide placement in the patent attorney field, they are, at the same time, hearing from popular media that patent eligible students are being bombarded with feedback that indicates that law is not a wealth-maximizing endeavor. ${ }^{144}$

${ }^{143}$ For example, before it merged with Hamline University School of Law in 2015, the William Mitchell College of Law marketed itself as a place to earn a degree in "practical wisdom." E.g., William Mitchell Prospective Student Packet, W.M. CoL. OF L. (Fall 2009). Although they never trademarked "practical wisdom," Mitchell Hamline trademarked a variation that melds two theories but emphasizes the practical: "Great in theory. Even better in practice." GREAT IN THEORY. EVEN BETTER IN PRACTICE., Registration No. 5036679 (emphasis mine).

144 See the discussion supra note 10. 
Therefore, it appears that the very fictitious claim that a law school is practical is what drives prospective patent-eligible, MECC Engineers students away. It was invented to provide an alternative narrative to the US News that there were reliable and objective reasons to choose one law school over another. It has the unintended consequence of exposing the reality of any law school: a legal education is and has been only connected to one specific job (being a lawyer) in the most remote terms. Law schools do and should teach students to think critically. A percentage of law graduates use that ability to become wealth-generating attorneys. Deciding which law school to attend is an inherently personal and subjective endeavor. To pretend that objective factors can explain an inherently subjective inquiry leads the law schools to seek other ways to distinguish themselves. This effort has caused some law schools to fish for the practicality fictional narrative rather than the "elite" fictional narrative. However, once you claim your graduates are suitable for only one job, when some do not ultimately do that job, it appears that you have failed in the one thing you were put here to do: educate lawyers. Patent-eligible students hearing this conflicting message may elect not to go to law school. MECC Engineers are some of the most rational people in American society, or at least believe themselves to be. ${ }^{145}$ So, the conflicting message that identical or nearly identical schools are either practical or elite provides a confusing backdrop that discourages rational people from engaging.

${ }^{145}$ Simon Makin, Scientists Think They're More Rational Than Other People, SCI. AM. (May 1, 2017), https://www.scientificamerican.com/article/scientists-think-theyremore-rational-than-other-people/./ 
$73.5 \%$ of all subsisting patent attorneys are MECC Engineers. ${ }^{146}$ MECC Engineers make up a small percentage of patent-eligible students at all law schools. ${ }^{147}$ If the majority (or, frankly, any) of these non-MECC Engineers are not getting patent jobs even though they have spent $20 \%$ of their law school curriculum in "practical" patent classes, it may be the false assumption that a practical education guarantees employment that is discouraging patenteligible law school applicants.

To be clear, MECC Engineers need to be considered separately from non-MECC patent-eligible prospective law students. MECC Engineers have a remarkably better chance of finding full employment as a patent attorney. However, perception is a difficult thing to overcome. It may be that the perception of under-employed non-MECC Engineers bleeds into the MECC people to discourage them from attending law school. This discouragement is only heightened when a law school offers significant patent practical education and does not deliver on the expected job for the student. When a law school claims to provide practical patent education, whether it is reality or not, students equate that "practicality" with "employment." When employment is not achieved, the fallibility of the myth of a practical patent education narrative is exposed.

Furthermore, it may be that rational MECC Engineers hear of or know or sense the disconnect between law schools where law schools invent differences to attempt to distinguish themselves when there is no real distinction. The scientific equivalent to the practical versus theoretical distinction between two equal players is like claiming that gravity works better at one school as opposed to another. That is, creating false distinctions that are not actual, significant differences confuses MECC Engineers and they go elsewhere for their graduate school education.

${ }^{146}$ Ralph D. Clifford, et al., A Statistical Analysis of the Patent Bar: Where are

the Software-Savvy Patent Attorneys, 11 N.C. J. LAW \& TECH. 223 (2010).

147 See supra notes 31-32 and accompanying text. 


\section{b. Hypothesis Two: Ph.D. as an alternative graduate degree}

With a $60 \%$ decline in MECC people going to law school in the last decade and an increase of some $40 \%$ in of the same types of people obtaining Ph.Ds., ${ }^{148}$ the logical assumption is that an increasing number of patent-eligible MECC Engineers are obtaining Ph.D.s in their fields of specialization instead of going to law school. This data is not specific to the person, so we do not know that each individual who got a Ph.D. instead of a J.D. would have obtained the J.D. but for some disincentive or reason. What we do know, is that the number of MECC Engineers in law is declining, while the number of MECC Engineers obtaining Ph.D.s is increasing.

That is, for some unknown reason, we have made a Ph.D in MECC more attractive than a J.D. More work needs to be done to determine the causative factors in this decision making process and determine what factors might be influenced and how to encourage more MECC Engineers to attend law school rather than obtaining a Ph.D in their field.

148 See discussion supra Part III. 


\section{c. Hypothesis Three: The Psychology of Bandwagon theory}

Another potential explanation for the dearth in patent-bar-eligible MECC Engineers in law school may be what is known in psychology as the "bandwagon effect." ${ }^{149}$ Applied here, it suggests that patent-bar-eligible MECC Engineers perceive some negative factor for their services and merely jump on the bandwagon and avoid law school even though there are plenty of patent attorney jobs for MECC Engineers. This bandwagoning is initiated by the Employment Hypothesis and perpetuated by the media. ${ }^{150}$ Under this theory, we assume that MECC Engineers hear that law school is not a wealth maximizing proposition and avoid it, even though, for MECC Engineers, patent law is wealth-maximizing.

149 "In the bandwagon effect, consumers demand a good because they want to be part of the crowd or to indulge in a fad." D. STEPHEN LANG \& NANCY Ruth FoX, CALCUlATED Futures: THEOlOGY, ETHICS, AND ECONOMICS 56 (2007).

${ }^{150}$ See discussion supra Part III and Part IV. 
This is unexpected because patent-bar-eligible students are often times perceived as the most rational law students in any given institution. ${ }^{151}$ If MECC Engineers are victims of the bandwagon theory as the data suggests, ${ }^{152}$ this should be an easy fix with rational education of this target group. Currently, there seems to be very few law schools that have tapped into this healthy stream of prospective students. ${ }^{153}$ As such, it is not surprising that these MECC Engineers are choosing to obtain a Ph.D. rather than J.D. because the only narrative they are hearing, supported by facts or not, is that it is a non-wealth-maximizing endeavor to go to law school.

If we hope to turn this trend around, and we do, it seems we need to provide an alternative narrative to what the media portrays as a bad idea. ${ }^{154}$ Law school admissions offices need to start explaining to graduate school candidates that there is a very healthy, wealthmaximizing alternative to a $\mathrm{Ph} . \mathrm{D}$.

${ }^{151}$ Scientists certainly perceive that they are more rational. See Makin, supra note 144; But recent work found that there isn't really that much difference, if at all. See Peter K.Williamson, The Creative Problem Solving Skills of Arts and Science Students-The Two Cultures Debate Revisted, 6 THINKING SKILlS AND CREATIVITY, no. 1, 2011; and see David Pearson, Exploding the Myth of the Scientific vs Artistic Mind, The Conversation, (April 21, 2016).

(http://theconversation.com/exploding-the-myth-of-the-scientific-vsartistic-mind-57843).

${ }^{152}$ Lang, supra note 148 at 56.

${ }^{153}$ Harvard is seemingly tapping into STEM prospective law students which may include MECC Engineers. See Claire E. Parker, To Keep Pace with Tech, Law School Seeks STEM Students, THE HARVARD CRIMSON (May 6, 2016), http://www.thecrimson.com/article/2016/5/6/HLS-admissionsSTEM-recruiting/.

${ }^{154}$ See supra note 10 and accompanying discussion. 


\section{d. Hypothesis Four: Law has no grand theory}

Another potential explanation for the dearth may be that MECC Engineers, trained in the scientific method where "grand theories" are used to explain the physical universe, sense the lack of grand theories in law and are, therefore, somehow chilled from attending law school. To put it in overly simplistic terms, $\mathrm{E}=\mathrm{Mc}^{2}$ no matter what language, culture, or theory is used to express it. In law, there is no metaphorical equivalent to $\mathrm{E}=\mathrm{Mc}^{2}$. This must be a discomforting fact to those trained in the scientific method. Perhaps it is this lack of a grand theory that scares some MECC students away from law school and encourages them to obtain a Ph.D. degree within their field of study instead. Law seems somehow "other," while, for example, a Ph.D. in electrical engineering, for an electrical engineer, is within his or her comfort zone. 
In law, there is always room to disagree. In contrast, engineering is founded on universally accepted scientific principles, leaving little or no room for disagreement. There are people who propose various grand theories of specific areas of law. Michael Moore devised a grand theory of criminal law, for example. ${ }^{155}$ However, this stops no one from disagreeing with this grand theory and presenting his or her own grand theory on criminal law. Our nation is comprised of at least 51 jurisdictions ${ }^{156}$ with differing opinions and interpretations, naturally allowing for differing opinions. ${ }^{157}$ But while law is inherently a compromise of competing opinions, science is not. ${ }^{158}$ Although theoretical physicists challenge various theories describing the natural universe and predict new ones from time to time, ${ }^{159}$ they do so based on observed data or mathematical formula. ${ }^{160}$ They just don't merely disagree. ${ }^{161}$ For example, you can't disagree with gravity. No matter how much one argues with, disbelieves, or distrusts gravity, it is still gravity and when an object is dropped, it falls. As Neil deGrasse Tyson says, "The good thing about science is that it's true whether or not you believe in it."162 Nowhere in law is there an equivalent notion.

155 This theory focuses on a functional approach to criminal law where the "function is to attain retributive justice" where "punish[ing] all and only those who are morally culpable in the doing of some morally wrongful action." MiCHAEL MOORE, PlaCING Blame: A General TheOry of the Criminal Law, 35 (1997). Yet, this does not prevent another academic, R. A. Duff for example, to write critically of this grand theory. R.A. Duff, Theorising Criminal Law: a 25th Anniversary Essay, 25 O.J.L.S. 353 (2005).

${ }^{156}$ Not to dismiss or discount the numerous Indian Tribes with recognized sovereignty or the established legal systems of the United States territories.

157 "Science tells us how we march. Law tells us where. Science seeks facts. Law seeks justice. Science describes. Law prescribes." Howard T. Markey, Science and Law: The Friendly Enemies, 30 IDEA: THE J. OF L. AND TECH. 13, 14 (1989). 
It may be that, whether conscious or not, to delve into the study of law for an MECC Engineer - or any law student for that matter- is to delve into the unknown with no discernable grand theory to explain its existence. Possibly, with no purpose or answer to discover, law is less appealing to an engineer with a hunger for answers than a law student with an appetite for argument.

${ }^{158} I d$.

${ }^{159}$ Grand Unification, SCHOLARPEDIA, http://www.scholarpedia.org/article/Grand_unification (last visited May 7, 2017).

${ }^{160}$ Markey, supra note 156 , at 14

161 That's not to say that scientists don't disagree about their findings; the process of peer review requires that scientists evaluate the findings of their colleagues. However, in recent years, openaccess scientific journals have proliferated. See John Bohannon, Who's Afraid of Peer Review? SCIENCE, Oct. 5, 2013, http://science.sciencemag.org/content/342/6154/60.full. With this proliferation comes a more relaxed review process for submitted articles, such so that an author can submit a fabricated scientific article and bring it almost to publication. Id.

162 Interview with Neil deGrasse Tyson, Real Time with Bill Maher (HBO television broadcast Feb. 4, 2011), https://www.youtube.com/watch?v=yRxx8pen6JY. 


\section{e. Hypothesis Five: Legal field fails to educate MECC Engineers about patent law}

A final contributing factor to the decline in MECC Engineers entering patent law might be simply a lack of knowledge about the field. Typically, while obtaining an undergraduate degree, MECC Engineers are exposed to the jobs directly utilizing their newly acquired skills; an electrical engineering major is exposed to electrical engineering jobs. However, MECC Engineers at university are rarely exposed to patent law as an employment opportunity. The historical increases and decreases of MECC Engineers attending law school are, therefore, quite confounding. Furthermore, engineering jobs fairs typically lack USPTO or patent attorney attendance ${ }^{163}$ limiting the breadth of knowledge to those who are already inclined to know about patent law as a job opportunity. Rather, patent attorneys and law schools can be found at prospective law student events, where, presumably, a MECC Engineer interested in the law has already learned of or considered a career in patent law. The opportunity to engage MECC Engineers is simply overlooked.

To fix this, the USPTO, patent attorneys, and law schools should make a concerted effort to increase the number of MECC Engineers at the undergraduate level exposed to patent law. Mere attendance at a university networking event or at job fair will, at least, inform MECC Engineers of the possibility of patent law as a career. It is certainly the duty of patent lawyers, law schools, and the USPTO to bring awareness to the profession, particularly where we have created the demand for these attorneys. ${ }^{164}$

163 See, e.g., Engineering Career Fair, Co. STATE UnIVERSITY, https://www.engr.colostate.edu/career_fair.php (last visited May 7, 2017).

164 See discussion supra Part II describing the problem. 


\section{Conclusion}

There is a marked disconnect between the abundant availability of MECC patent jobs and the dearth of MECC patent-eligible students attending law school. There is a viable market in the field of patent law for people with mechanical, electrical, chemical, or computer engineering degrees, and yet MECC law students continue to decline to attend.

There are many potential contributing factors to the decline in MECC law students. The most likely factor, however, is the misinformation that the MECC Engineer receives about the job prospects of patent attorneys compared to Ph.D. holders - that law is affirmatively a non-wealth maximizing endeavor and a Ph.D. is relatively unknown and therefore the holder can place what value he or she chooses. As a result of this misinformation, the MECC Engineer, once interested in law school, appears to turn his or her back on the idea and pursues a Ph.D. instead. However, knowing that this information is incorrect - that patent attorneys have a higher median salary than Ph.D. Engineers and can obtain the degree in a shorter time even though accruing more student debt- the MECC Engineer still forgoes law school. To blame are law schools, patent attorneys, the USPTO, and the media - all who are guilty (at least in part) of perpetuating the stereotype that law school is not a wealthmaximizing proposition even for patent attorneys. With the proper information and education of MECC Engineers about the job market for patent attorneys, this downward spiral can be stopped and hopefully reversed.

Though not every MECC Engineer will choose law school over a Ph.D., we still encourage law schools, patent lawyers, the USPTO, and the media to do a better job to encourage and attract MECC engineers to come to law school. It is a wealth-maximizing career for those individuals and it is vitally important to keep the United States economy competitive. 


\section{Cybaris ${ }^{\circledR}$}

Cybaris ${ }^{\circledR}$, an Intellectual Property Law Review, publishes non-student articles and student comments on all areas of intellectual property law, including patents,

copyrights, trademarks, licensing, and related transactional matters.

mitchellhamline.edu/cybaris

\section{Intellectual Property Institute}

Cybaris ${ }^{\circledR}$ is a publication of the Intellectual Property Institute at Mitchell Hamline School of Law. mitchellhamline.edu/ip

\section{$\mathrm{MH}$}

MITCHELL | HAMLINE

School of Law

(c) Mitchell Hamline School of Law

875 Summit Avenue, Saint Paul, MN 55105

mitchellhamline.edu 